\title{
Occurrence of Helminthosporium species on cereals in Finland in 1971-1973
}

\author{
KAIHO MÄKELÄ \\ Department of Plant Pathology, University of Helsinki, Viikki
}

\begin{abstract}
This study was carried out on Helminthosporium species found on cereals (Avena sativa L., Hordeum vulgare L., Triticum aestivum L., Secale cereale L.) and couch grass (Agropycon repens (L.)PB.) The objective was to ascertain their distribution and general significance in Finland. The results were obtained from samples of cereals gathered in 2040 fields all over the country during the growing season 1971-1973. The samples of couch grass (approx. 170 samples) were collected in fields and the borders of fields.

The fungi in all the samples were examined by microscope, using the blotter method and with cultures.

Many Helminthosporium species were found to be very common and abundant on cereals, especially in 1972, throughout the country and as far as Lapland. The imperfect stages (conidia) of the fungi occurred dominantly and in abundance, whereas the perfect stages of the fungi were found only occasionally at all times. Pyrenophora tritici-repentis (Died.) Drechs. on Agropyron repens was exceptional in this respect.

The most widespread and common Helminthosporium fungi were the following species:

$H$. avenae Eidam was found to be very common and abundant in more than 60 per cent of the oat fields and in nearly 90 per cent of the localities that were studied throughout the country. These figures apply to seedlings as well.

$H$. gramineum Rabenh. ex Schlecht was found frequently in more than 30 per cent of the spring barley fields and in about 55 per cent of the localities that were studied. It was very common and abundant in Ostrobothnia and the northern parts of the country and was frequent on six-rowed barley, ton.

$H$. teres Sacc. was found to be common and abundant in nearly 60 per cent of the spring barley fields and in nearly 90 per cent of the localities that were studied. These figures apply to the seedlings as well and are especially representative of observations made in the western and southern parts of the country. The fungus was more common on six-rowed than on two-rowed barlev

$H$. tritici-repentis Died, was found to be moderately common in southern and southwestern Finland as follows: in nearly 30 per cent of the spring wheat fields and in 40 per cent of the localities studied; in 17 per cent of the winter wheat fields and in 23 the winter rye fields; for both the latter mentioned moderate abundance was observed in more than 50 per sent of the localities studied. On Agropyron repens the fungus was very common and abundant in 50 per cent of the samples and in nearly 60 per cent of the localities studied. In addition, the perfect stage of the fungi, Pyrenophora triticirepentis (Died.) Drechs. with mature ascoma and ascospores was found in about $1 / 4$ of the samples examined throughout the country.
\end{abstract}


H. sativum Pammel, King and Bakke was found to be moderately common and abundant in about 30 per cent of the spring barley fields and in 55 per cent of the localities studied throughout the country, being most common in southern and southwestern Finland. The fungus was more common on two-rowed than on six-rowed barley. The fungus was observed to be moderately common in 9 per cent of spring wheat fields and in nearly 20 per cent of the localities studied. In all fields $H$. sativum appeared sporadically alsn in seedlings on spring barley and spring wheat as well as on the roots of barley. The fungus was found to be moderately common also in oat fields, but only in 1972, whereas on winter wheat and winter rye its occurrence was only rare and sporadic.

An undetermined Helminthosporium species, like $H$. gramineum or $H$. teres, was found to be sparce but moderately common, in about 10 per cent of the spring wheat fields and in nearly 20 per cent of the localities studied. It occurred only occasionally on winter wheat and on winter rye fields.

It is not known how fungi damage affects crop yields. At least $H$. gramineum, $H$. teres and $H$. sativum on spring barley, as well as $H$. avenae on oats, caused severe damage to plants and occurred commonly throughout the country.

\section{Introduction}

Several Helminthosporium species are known to be serious causers of leaf spot diseases on cereals cultivated all over the world (SPRAGUE 1950). In Scandinavia these diseases have been known since the last century (RAvN 1901, JøRSTAD 1945), but due to the extensive use of mercurial fungicides they have continued to play only a minor role, except in the northern parts of the countries (Fritz 1966, Kolk 1966, Kolk and Karlberg 1973, Andersen 1955, Jørgensen 1969, Hansen and Magnus 1969, OveraA 1972).

In recent years, however, there has been a marked increase in the prevalence of Helminthosporium species, especially on barley, e.g. in Norway (Hansen and Magnus 1969), Denmark (SmedegÅrd-Petersen 1971, 1972 a, 1974) and Finland (BLomouist 1970).

There may be several reasons for this: the increased acreage devoted to cultivation of barley, the influence of new barley varieties and climatic conditions (SMEdEgÅRD-Petersen 1972 b, 1974, MÄKelä 1972). Their abundance may also be due to the use of undressed seed (LIHNELl 1969, BLomouist 1970, OVERAA 1972).

In Finland there are thus far only a few studies about the Helminthosporium species causing diseases on cereals. However, these fungi have been known for a long time and they have continually caused serious damage, especially on barley (Liro 1917, Halkilahti 1971). In recent years there has been increased the interest in the Helminthosporium species of cereals (Mäkelä 1971, 1972, Rekola et al. 1970, Halkilahti 1971, 1973 a, 1973 b).

Cereals are grown on about 46 per cent of Finland's total field area (2 665000 hectars). More than 90 per cent of the cereals area is covered by spring cereals (oats, barley, wheat); less than 10 per cent by winter cereals (wheat, rye). Oats (area $19 \%$ ) and barley (area $17 \%$ ) are among the most important cultivated plants in Finland and they thrive even in the northern parts of the country. Spring wheat (area less than $5 \%$ ), winter wheat (area $2 \%$ ) and winter rye (area $2 \%$ ) are grown in the southern and central parts of the country. The proportion of barley is showing an increase in recent years, 
whilst the acreage devoted to wheat and rye is decreasing (Official statistics of Finland 1973).

This study is part of a research project dealing with spot diseases on cereals, and specifically with the pathogens causing these diseases (cf. MäKEL 1972 . 1974). The purpose of the present study is to clarify the occurrence of Helminthosporium species on cereals. The study is based on samples of cereals whicnwere gathered in farmers' fields throughout the contry over a three year period (1971-1973).

\section{Materials and Methods}

The bulk of the cereal samples (Table 1) was gathered from southwestern and southern Finland; samples of barley and oats also came from northern Finland, particularly in 1973. Only rare samples were gathered from Uusimaa, South Savo and South Karelia in 1973, owing to exceptionally dry weather.

The samples of barley were gathered in $\mathbf{8 0 3}$ felds from $\mathbf{2 5 1}$ localities. About 80 per cent of these were six-rowed varieties and about 20 per cent were tworowed varieties. The samples of oats came from 181 localities, tne total samples numbering 415 . The samples of spring wheat were collected in 222 fields from 111 localities, the corresponding figures for winter wheat being 259 fields and 72 localities. The samples of winter rye came from 112 localities, the total samples numbering 341 .

The samples of Agropyron repens (c. 170 samples) were collected in fields and the borders of fields in about $\mathbf{8 0}$ localities throughout the country.

The bulk was gathered at a growth stage when the grain was milky ripe, chiefly from late July to early August (20 July - 14 Aug., 1971; 16 July -8 Aug., 1972; 21 July - 14 Aug., 1973). The samples of winter wheat and rye as well as of Agropyron repens were gathered in May also. Furthermore, observations of appearance of diseases were made in fields during the entire growing season.

As a rule it was attempted to take the representative samples from large areas of the field. In general the samples were garhered in the same field only once. In most cases the variety remained unknown.

The following cultivated varieties of cereals have been commonest during this time in Finland (Official statistics of Finland 1973). Oats: Hannes, Pendek, Titus, Sisu, Kyrö, Nip; spring barley, two-rowed varieties: Karri, Ingrid; six-rowed varieties: Otra, Pirkka, Pomo, Paavo; spring wheat: Ruso, Apu, Norröna, Drott, Svenno, Touko, Diamant II; winter wheat: Vakka, Elo, Linna, Nisu; winter rye: Pekka, Toivo, Ensi, Voima.

The leaves were checked for diseases by ocular examination on the basis of symptoms. Fungi causing diseases were determined in the following way: 1. Diseases leaves were kept on moist blotter paper in Petri dishes for severaldays, after which the fungi tha thad grown were examined with a stereomicroscope. 2. Microscope slides were made from the leaves and, using these, the fungi were measured and photographed. 3. One-spore cultures of the fungi that had developed on the leaves were made on PDA (Difco). The stands were compared with each other. The results are grouped by biological provinces (HeIKINHEIMo and RAATIKAINEN 1971). 
Table 1. Frequency of Helminthosporium species as a per cent of samples of cereals gathered in various localities and fields during the period $1971-1973$.

\begin{tabular}{|c|c|c|c|c|c|c|c|c|c|c|}
\hline \multirow[b]{2}{*}{ Cereals } & \multirow[b]{2}{*}{ Year } & \multicolumn{2}{|c|}{$\begin{array}{c}\text { The samples } \\
\text { researched }\end{array}$} & \multicolumn{7}{|c|}{$\begin{array}{l}\text { Helminthosporium } \text { species, \% of fields } \\
\text { researched }\end{array}$} \\
\hline & & 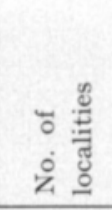 & $\ddot{\circ} \frac{y}{0}$ & $\begin{array}{c}H . \\
\text { avenae }\end{array}$ & $\begin{array}{c}H . \\
\text { gra- } \\
\text { mineum }\end{array}$ & $\begin{array}{c}H . \\
\text { teres }\end{array}$ & $\begin{array}{c}\text { H. } \\
\text { sativum }\end{array}$ & $\begin{array}{r}H . \\
\text { tritici- } \\
\text { repentis } \\
\text { pe } \\
\mathrm{s}\end{array}$ & $\begin{array}{l}\quad H e l \\
\quad \text { tho } \\
\text { s riun } \\
\text { erfetc } \\
\text { stage }\end{array}$ & $\begin{array}{l}\text { min- } \\
\text { spo- } \\
n \text { spp. }\end{array}$ \\
\hline \multirow{4}{*}{ 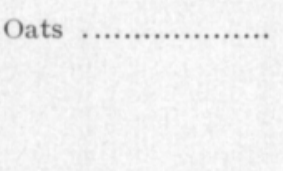 } & 1971 & 50 & 73 & 61 & - & - & 1 & - & - & - \\
\hline & 1972 & 142 & 233 & 74 & - & - & 14 & - & - & - \\
\hline & 1973 & 48 & 109 & 46 & - & - & 2 & - & - & - \\
\hline & $1971-73$ & 181 & 415 & 63 & - & - & 9 & - & - & - \\
\hline \multirow{3}{*}{$\begin{array}{r}\text { Barley } \ldots \ldots \ldots \ldots . . . \\
\text { Two-rowed } \ldots \ldots . . \\
\text { Six-rowed } \ldots \ldots \ldots\end{array}$} & 1971 & 69 & 157 & - & 34 & 59 & 16 & - & - & - \\
\hline & & 25 & 39 & - & 18 & 46 & 21 & - & - & - \\
\hline & & 58 & 117 & - & 39 & 64 & 15 & - & - & - \\
\hline \multirow{3}{*}{ 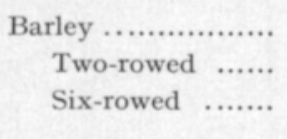 } & 1972 & 135 & 348 & - & 24 & 67 & 37 & - & - & - \\
\hline & & 47 & 59 & - & 29 & 68 & 59 & - & - & - \\
\hline & & 113 & 289 & - & 23 & 66 & 33 & - & - & - \\
\hline \multirow{3}{*}{$\begin{array}{r}\text { Barley } . . . . . . . . . . . . . \\
\text { Two-rowed } \ldots . . . \\
\text { Six-rowed } \ldots \ldots . .\end{array}$} & 1973 & 124 & 299 & - & 40 & 45 & 25 & - & - & - \\
\hline & & 23 & 52 & - & 19 & 37 & 33 & - & - & - \\
\hline & & 112 & 247 & - & 44 & 47 & 24 & - & - & - \\
\hline \multirow{3}{*}{$\begin{array}{r}\text { Barley } \ldots . . . \ldots . . . . . \\
\text { Two-rowed } \ldots \ldots . . \\
\text { Six-rowed } \ldots \ldots \ldots\end{array}$} & $1971-73$ & 251 & 803 & - & 32 & 57 & 29 & - & - & - \\
\hline & & 83 & 150 & - & 23 & 51 & 40 & - & - & - \\
\hline & & 234 & 653 & - & 34 & 59 & 26 & - & - & - \\
\hline \multirow[t]{3}{*}{ Spring wheat ........ } & 1972 & 88 & 140 & - & - & - & 10 & 26 & - & 14 \\
\hline & 1973 & 62 & 82 & - & - & - & 9 & 32 & - & 9 \\
\hline & $1972-73$ & 111 & 222 & - & - & - & 9 & 27 & - & 11 \\
\hline \multirow[t]{3}{*}{ Winter wheat ........ } & 1972 & 62 & 112 & - & - & - & 1 & 26 & - & 7 \\
\hline & 1973 & 56 & 147 & - & - & - & 4 & 10 & - & 1 \\
\hline & $1972-73$ & 72 & 259 & - & - & - & 3 & 17 & - & 4 \\
\hline \multirow[t]{3}{*}{ Winter rye ............ } & 1972 & 90 & 201 & - & - & - & 0 & 29 & - & 4 \\
\hline & 1973 & 62 & 140 & - & - & - & 0.7 & 13 & - & 0 \\
\hline & $1972-73$ & 112 & 341 & - & - & - & 0.3 & 23 & - & 3 \\
\hline \multirow[t]{3}{*}{ Couch grass ... } & 1972 & 73 & 131 & - & - & - & - & 45 & 22 & - \\
\hline & 1973 & 21 & 38 & - & - & - & - & 68 & 32 & - \\
\hline & $1972-73$ & 82 & 169 & - & - & - & - & 50 & 24 & - \\
\hline
\end{tabular}

\section{Climate and Weather}

Duration of the growing season $\left(+5^{\circ}-+5^{\circ} \mathrm{C}\right)$ in Finland is $120-180$ days. Mean temperature varies from $10^{\circ}$ to $13^{\circ} \mathrm{C}$ during this period (KoLKKI 1966). The average monthly precipitation varies from 35 to $80 \mathrm{~mm}$ and is lower early in the growing season than it is in the autumn (HELIMÄKI 1967). 
The weather in spring and summer in 1971 was characterised by the alternation of one or two week periods of exceptional cold or heat. There was very little precipitation during the growing season ecxept for the early part of August, particularly in southern Finland.

The weather during the growing season of 1972 as well as from May to August of 1973 was exceptionally warm; in July it was even $2-4^{\circ} \mathrm{C}$ higher than normal. Precipitation conditions varied greatly in different parts of the country. In 1972 there was little rain in May and in June, whilst in August there was quite a lot of rain in southern and central Finland. During the entire growing season 1973 the amounts of precipitation were smaller than normal. Uusimaa and Kymenlaakso in particular suffered from drought.

The winter of $1970-1971$ was long with abundant snowfall. The winters of 1971-1972 and 1972-1973 were much milder than normal (Meteorol. Yearb. Finland 1971, 1972, 1973).

\section{Results}

In the present study the old form of undivided genus Helminthosporium is used instead of genera Drechslera and Bipolaris (cf. Shozmaker 1959). The imperfect stages of Helminthosporium species are used instead of the perfect stages of Pyrenophora and Cochliobolus species because the former stage of the fungi appeared abundantly in Finland, whereas the latternamed stages are found rarely or not at all (cf. MÄKELÄ 1971).

\section{Helminthosporium avenae}

Helminthosporium avenae Eidam, syn. Drechslera avenae (Eidam) Scharif, perfect stage: Pyrenophora avenae Ito \& Kurib. Syn. cf. Shoemaker 1962: 815.

The fungus causes seedling blight and leaf stripe on young oat plants as well as leaf spot or leaf blotch on the oat plants at maturity. The earlier phase is considered important (Turner and Millard 1931, Dennis 1933, Müller 1963).

The fungus is seed-borne and the most important source of infection is the resting mycelium on the grain (Turner and Millard 1931, de Tempe 1964).

$H$. avenae is widespread but only important in cool and moist climates, which in fact offer the conditions that suit the crop best (SPRAGUE 1950, de TEMPE 1964, Смi map no. 105).

In Europe the fungus is known to be common and destructive in the wetter, northern and western areas of British Isles (BUtLER and Jones 1949). It occurs also in Germany (Müller 1963). In Scandinavia H. avenae has been known in Norway since 1891. There it has afflicted oat seedlings (JorstaD 1945). Today the fungus causes some damage to roots and culms of oats (OveraA 1972). In Denmark $H$. avenae has been known on oat plants and on seed since 1896 (RAVN 1901). It is very common but the fact that it causes leaf blotch on oats has been overlooked (ANDERSEN 1955). Today the fugus is little known in Sweden (Fritz 1965, KoLK 1966). 
In Finland, too, $H$. avenae is apparently considered to be of negligible significance because up to now it has not attracted attention. According to Halkilahti (1973 a) H. avenae infection on samples of oat seed was common in the harvests of 1967 and 1972. The fungus was found on seed produced throughout the country as far as North Ostrobothnia. In field trials in 1968 and 1969 at Viikki, Helsinki, the crop losses caused by $H$. avenae on oats were $2-10 \%$ (REKola et al. 1970).

$H$. avenae infects, besides oats (Avena spp.), also barley and other species of graminae (Sprague 1950, Braverman 1960, Shoemaker 1962, Ammon 1963).

In this study $H$. avenae was found to be common on oats throughout the country as far north as Lapland (Inari) (Fig. 1). The fungus was found in the folowing localities:

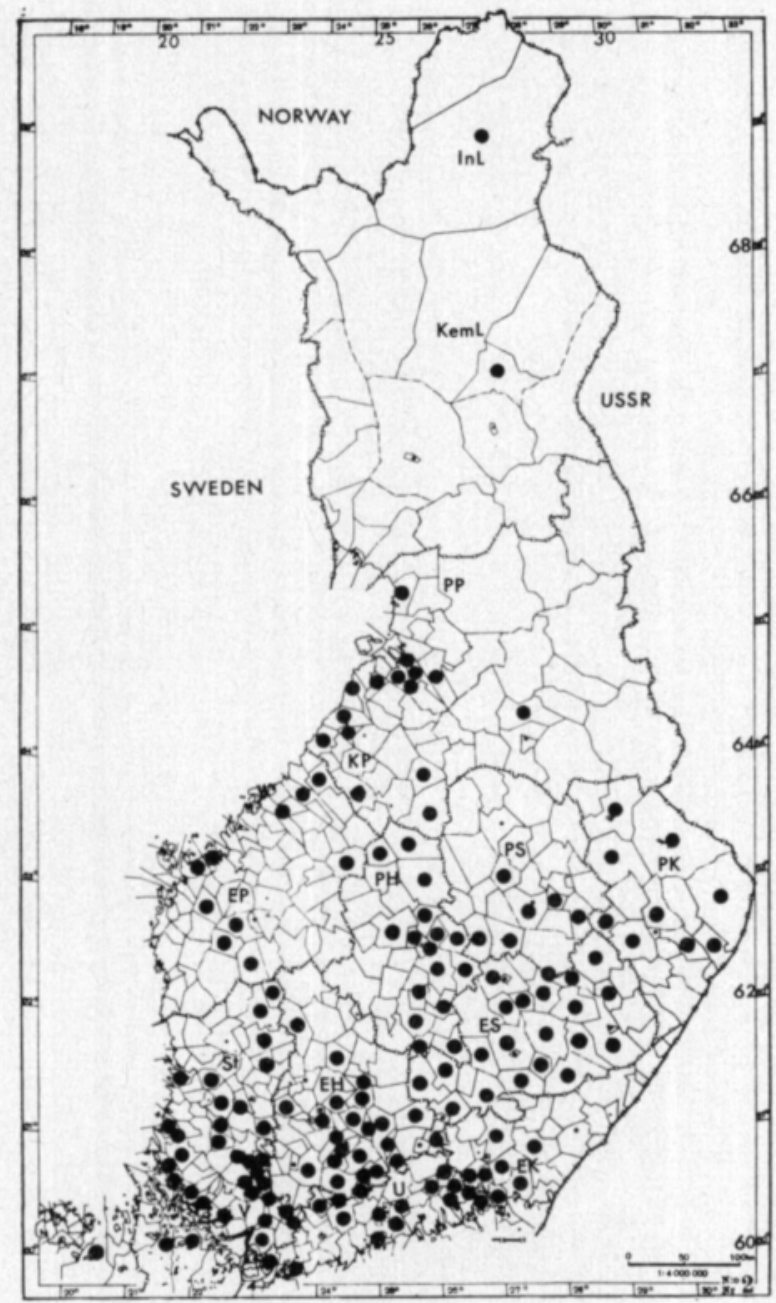

Fig. 1. The occurrence of Helminthosporium avenae on oats (Avena sativa) by localities in Finland during the period $1971-1973$. 
A: $\quad$ Föglö;

V: Kalanti, Karinainen, Karkkila, Kiikala, Kodisjoki, Korppoo, Koski T1., Kuusjoki, Laitila, Lemu, Marttila, Nauvo, Perniō, Piikkiō, Pusula, Raisio, Salo, Suomusjärvi, Tenhola, Vehmaa, Vihti;

U: Anjala, Artjärvi, Elimäki, Espoo, Helsinki mlk., Hyvinkää, Lapinjärvi, Liljendal, Myrskylä, Pornainen, Pyhtää, Ruotsinpyhtää, Sipoo, Snappertuna, Tuusula;

EK: Karhula, Sippola, Vehkalahti;

St: Hämeenkyrö, Ikaalinen, Keikyä, Kihniō, Kokemäki, Kullaa, Köyliö, Loimaa, Loimaa mlk., Mellilä, Oripää, Parkano, Pori, Punkalaidun, Rauma, Säkylä;

EH: $\quad$ Asikkala, Hartola, Hattula, Hauho, Hausjärvi, Heinola mlk., Hämeenlinna, Janakkala, Korpilahti, Koski Hl., Kuhmalahti, Kuru, Kärkölä, Lammi, Loppi, Luhanka, Luopioinen, Nastola, Orivesi, Pälkäne, Renko, Riihimäki, Sysmä, Sääksmäki, Tammela, Tuulos, Vesilahti;

ES: Anttola, Enonkoski, Hirvensalmi, Joutsa, Juva, Luumäki, Mikkeli, Mäntyharju, Puumala, Ristiina, Sulkava, Sääminki;

EP: Ilmajoki, Jalasjärvi, Koivulahti, Kurikka, Laihia, Maksamaa;

PH: Hankasalmi, Jyväskylä mlk., Konginkangas, Konnevesi, Kinnula, Laukaa, Pihtipudas, Rautalampi, Saarijärvi, Sumiainen, Suolahti, Toivakka, Viitasaari, Äänekoski,

PS: Haukivuori, Heinävesi, Joroinen, Kangaslampi, Kuopio, Maaninka, Pieksämäki, Rautalampi, Riistavesi, Suonenjoki, Tuusniemi, Varkaus, Virtasalmi;

PK: Ilomantsi, Juuka, Kiihtelysvaara, Kontiolahti, Liperi, Nurmes, Outokumpu, Pielisjärvi, Tuupovaara;

KP: Kalajoki, Kannus, Krunupyy, Kälviä, Kärsämäki, Merijärvi, Perho, Pyhäjoki, Pyhäjärvi, Raahe, Revonlahti, Sievi;

PP Ii, Kempele, Liminka, Muhos, Temmes, Tyrnävä;

Kn: Paltamo;

KemL: Pelkosenniemi;

InL: Inari.

Prefect stage: U: Snappertuna 24. 5. 1972.

Table 2. Frequency of Helminthosporium avenae and $H$. sativum on oats (Avena sativa) in the fields researched in 1971-1973.

\begin{tabular}{|c|c|c|c|c|}
\hline \multirow{3}{*}{$\begin{array}{l}\text { Biological provinces } \\
\text { of Finland }\end{array}$} & \multicolumn{2}{|c|}{ The samples researched } & \multirow{2}{*}{\multicolumn{2}{|c|}{$\begin{array}{c}\text { Helminthosporium } \\
\text { species, \% of fields } \\
\text { researched }\end{array}$}} \\
\hline & \multirow{2}{*}{$\begin{array}{l}\text { No. of } \\
\text { localitie }\end{array}$} & \multirow{2}{*}{$\begin{array}{l}\text { No. of } \\
\text { fields }\end{array}$} & & \\
\hline & & & $\begin{array}{c}\text { H. avenae } \\
\text { Fig. } 1\end{array}$ & $\begin{array}{c}\text { H. sativum } \\
\text { Fig. } 13\end{array}$ \\
\hline 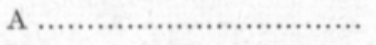 & 1 & 1 & $(100)$ & $(0)$ \\
\hline 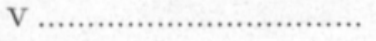 & 24 & 44 & 64 & 5 \\
\hline 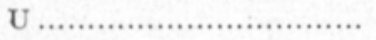 & 18 & 49 & 53 & 22 \\
\hline 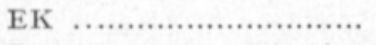 & 3 & 7 & 71 & 43 \\
\hline 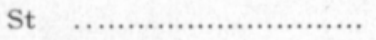 & 20 & 39 & 62 & 10 \\
\hline 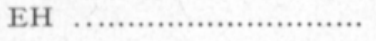 & 27 & 81 & 54 & 7 \\
\hline 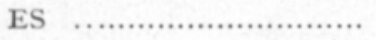 & 15 & 31 & 71 & 7 \\
\hline 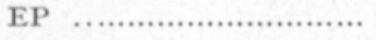 & 6 & 20 & 65 & 10 \\
\hline 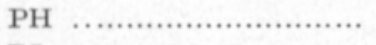 & 16 & 49 & 65 & 4 \\
\hline 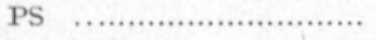 & 13 & 26 & 73 & 0 \\
\hline 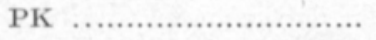 & 10 & 24 & 71 & 0 \\
\hline 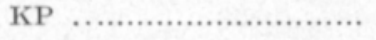 & 18 & 30 & 67 & 7 \\
\hline 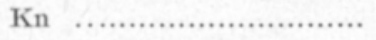 & 3 & 5 & 20 & 20 \\
\hline 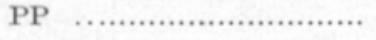 & 6 & 7 & 100 & 14 \\
\hline KemL ....................... & 1 & 2 & $(50)$ & $(0)$ \\
\hline 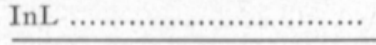 & (1) & $(12)$ & $(8)$ & $(0)$ \\
\hline 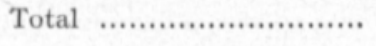 & 181 & 415 & & \\
\hline
\end{tabular}



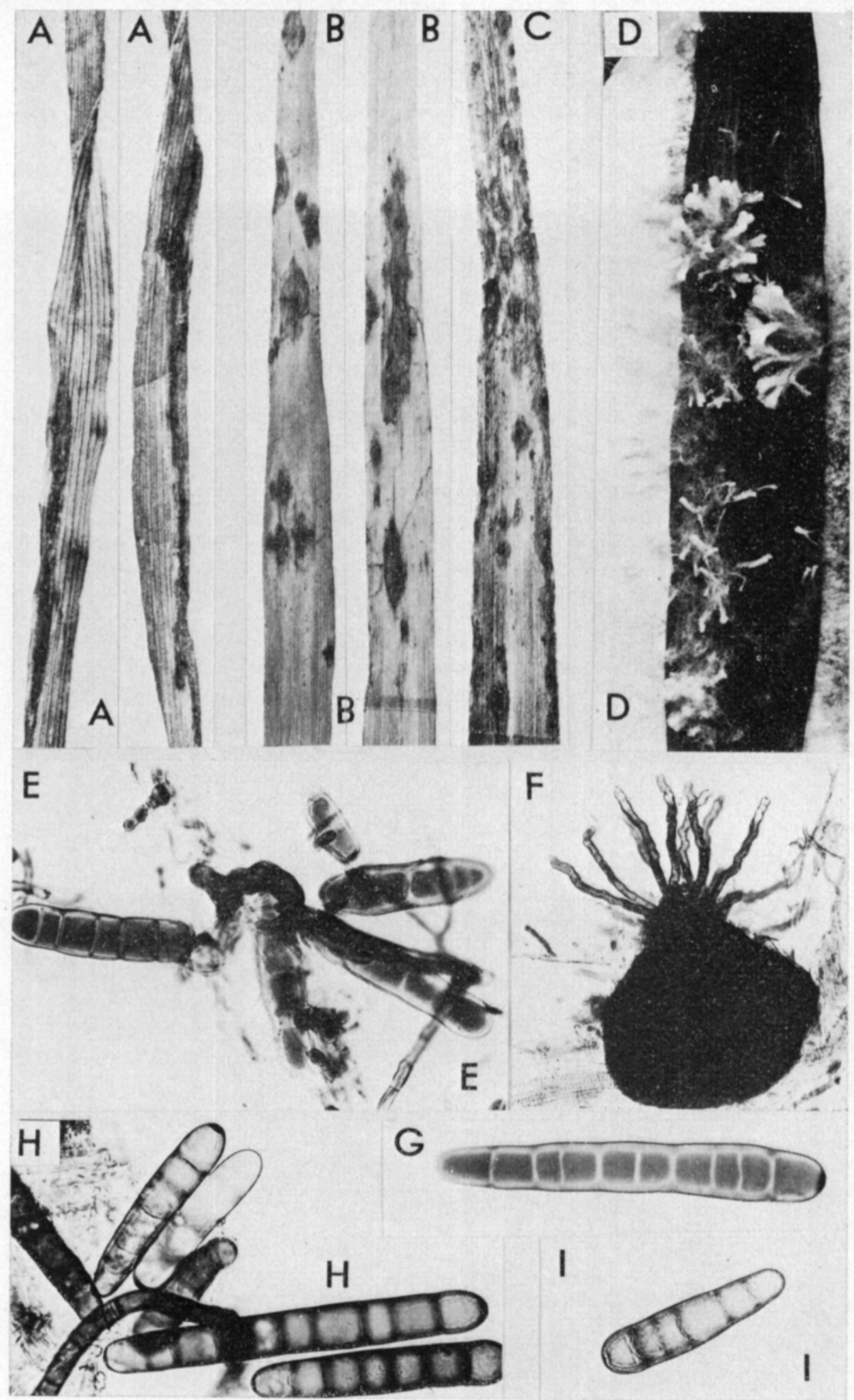

Fig. 2. Helminthosporium avenae on oats (Avena sativa). A: the primary leaf stripe on seedling in the middle of June, B-C: the secondary leaf spot on leaves in August, D: the mycelial tufts sprout up on the leaf on moist blotter, E: conidiophores and conidia on oat stubble in May, F: Pyrenophora avenae's ascoma on oat stubble in May, G: the conidium on oat leaf in August. Helminthosporium spp. H: conidia on spring wheat (Triticum aestivum), I: the conidium on winter rye (Secale cereale). A-C: x 1, D: x 2, F: x 100, E, H, I: x 500, G: x 1000. 
$H$. avenae was encountered in different years in an average $63 \%$ (range $46-74 \%$ ) of the oat fields (415 fields) and in $87 \%$ of the localities (181 localities) examined (Table 1). The occurrence of the fungus was fairly uniform in different parts of the country (Table 2).

The fungus was found on seedlings, sometimes abundantly in, for instance peat soil in early summer. The first two or three leaves of an infected seedling show brown stripes with yellow-reddish margins (Fig. 2 A) (cf. REKOLA et al. 1970). Leaf damage was commoner, however, at maturity (cf. JøRsTAD 1945). Initially it took the form of spots with an reddish-orange margin surrounding a dead, brown area. The spots may join together (Fig. 2 C) (cf. Müller 1963). In late summer the fungus was very common. The disease occurred equally throughout fields.

$H$. avenae formed a very characteristic tufty, white cotton growth or coremium on leaves of oats in humid conditions (Fig. 2 D) (cf. Müller 1963, REKola et al. 1963). Conidia also formed abundantly, particularly on diseased mature leaves (Fig. 2 G). The perithecial stage and conidia were found only accidentally on stubble (Snappertuna, 24. 5. 1972) (Fig. 2 E, F).

\section{Helminthorporium gramineum}

Helminthosporium gramineum Rabenh. ex Schlecht., syn. Drechslera graminea (Rabenh. ex Schlecht.) Shoem., perfect stage: Pyrenophora graminea Ito \& Kurib. Syn. cf. Shoemaker 1962: 825.

The fungus causes leaf stripe of barley and it occurs in most of the world's barley-growing areas (DrehCSLER 1923, Sprague 1950). The fungus is seedborne and usually is overwintered by mycelium in the pericarp (RAvN 1901, de TEMPE 1964).

This disease is generally of limited importance (de TEMPE 1964) but still causes crop losses in many countries, e.g. in the USSR (Sнснекоснікнina 1964, Rasvlev and Kraotsova 1970) and in Czechoslovakia (Zekovic 1970). In Scandinavia $H$. gramineum has been extremely scarce in Denmark for a long time (ANDERsen 1955, Jørgensen 1969). The disease is found to some extent in Sweden (KolK 1966) and in Norway (Hansen and Magnus 1969), though its economic significance is small. However, the disease has again occurred in greater abundance, particularly on six-rowed barley, in recent years in the central and northern parts of these countries (Linhell 1969, OveraA 1972, Kolk and Karlberg 1973).

In Finland $H$. gramineum has long been common (LiRo 1917) and continues to be so (Halkilahti 1971, Mäkelä 1972). According to field tests at the State Seed Testing Station, stripe disease has occurred in about $40-50 \%$ of all the samples of barley examined during the last thirty years (HALKILAHTI 1971). In 1970 and $1971 \mathrm{H}$. gramineum was also found in about $30 \%$ of the barley fields located in the southern and central parts of the country (MÄKEL ̈̈ 1972).

In this study $H$. gramineum was encountered on barley throughout the country as far as Lapland (Inari) (Fig. 3). The fungus was found in the following localities: 


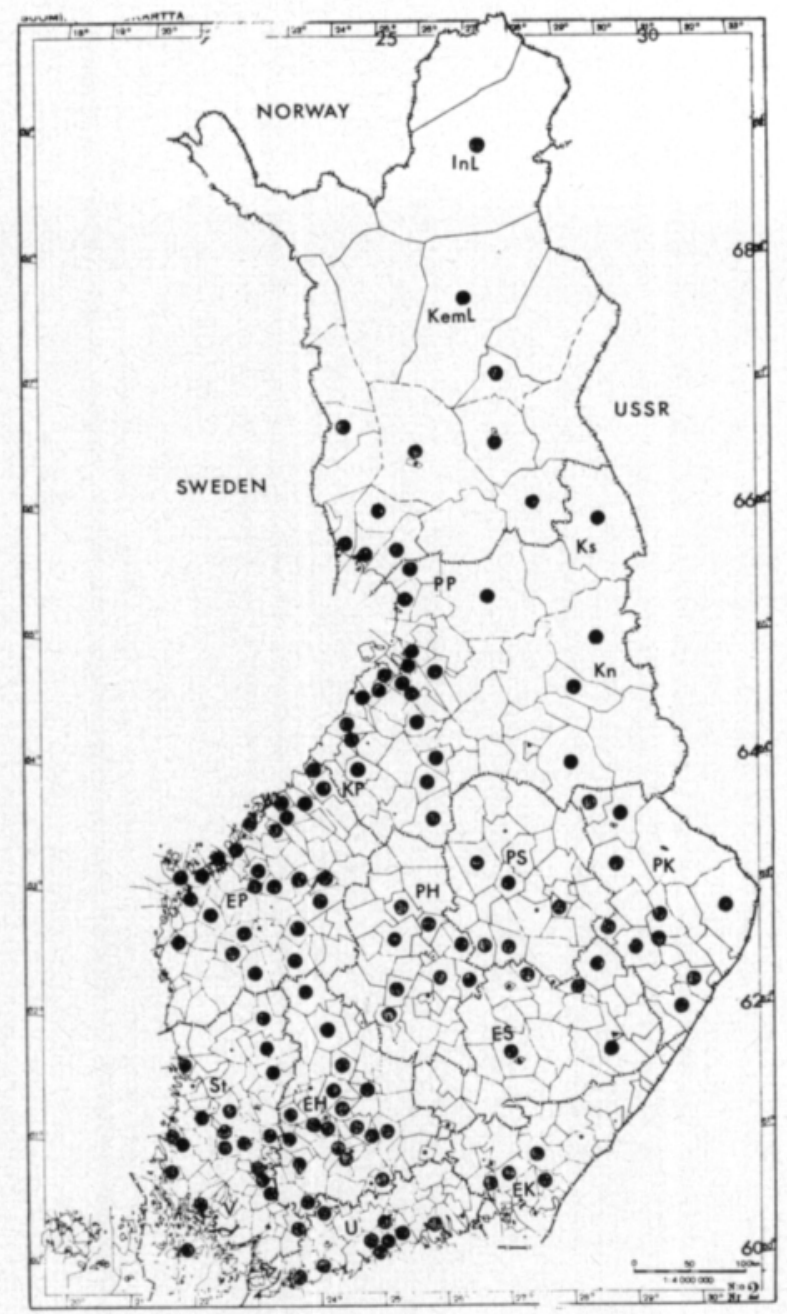

Fig. 3. The occurrence of Helminthosporium gramineum on spring barley (Hordeum vulgare) by localities in Finland during the period $1971-1973$

V: Kalanti, Kodisjoki, Koski T1., Masku, Nauvo, Pusula, Suomusjärvi;

U: Anjala, Helsinki, Inkoo, Porvoo mlk., Sipoo, Snappertuna, Vantaa, Tuusula;

EK: Miehikkälä, Sippola;

St: Ahlainen, Hämeenkyrō, Ikaalinen, Kiukainen, Kokemäki, Köyliö, Loimaa mlk., Mellilä, Parkano, Punkalaidun, Rauma, Säkylä, Vampula;

EH: Forssa, Hattula, Hauho, Hausjärvi, Hämeenlinna, Jämsänkoski, Kangasala, Lammi, Orivesi, Pälkäne, Ruovesi, Sahalahti, Somerniemi, Sääksmäki, Toijala, Tuulos, Urjala, Vesilahti;

ES: Kangaslampi, Luumäki, Mikkeli, Sääminki;

EP: Alavus, Ilmajoki, Jalasjärvi, Kauhava, Koivulahti, Kuortane, Kurikka, Laihia, Maksamaa, Mustasaari, Vaasa, Ylihärmä, Ylimarkku:

PH: Hankasalmi, Kannonkoski, Konginkangas, Konnevesi, Laukaa, Petäjävesi, Rautalampi, Saarijärvi, Virrat;

PS: Heinävesi, Jäppilä, Maaninka, Pielavesi, Riistavesi, Suonenjoki;

PK: Ilomantsi, Joensuu, Juuka, Kitee, Kontiolahti, Liperi, Nurmes, Outokumpu, Tohmajärvi, Valtimo;

KP: Alahärmä, Alajärvi, Himanka, Kannus, Kruunupyy, Kokkola, Kälviä, Kärsämäki, Lappajärvi, Merijärvi, Munsala, Pattijoki, Pietarsaari, Piippola, Pyhäjoki, Pyhäjärvi, Rantsila, Revonlahti, Vimpeli, Ylivieska, Ähtävä; 
Kn: Hyrynsalmi, Sotkamo, Suomussalmi;

PP: Ii, Kemi, Kemijärvi, Kempele, Kuivaniemi, Liminka, Lumijoki, Muhos, Oulu, Pello, Pudasjärvi, Rovaniemi, Simo, Temmes, Tervola, Tornio;

Ks: Kuusamo, Posio;

KemL: Pelkosenniemi, Sodankylä;

InL: Inari

Perfect stage: V: Tenhola, 24. 5. 1972,

U: Helsinki (Viikki), 6. 6. 1972.

H. gramineum was found in different years in an average $32 \%$ (range $24-40 \%$ ) of the fields (803 fields) and in $54 \%$ of the localities (251 localities) studied (Table 1). The fungus was much commoner in six-rowed varieties $(23-44 \%)$ than in two-rowed varieties $(18-29 \%)$, an observation which is widely confirmed (HAnsen and Magnus 1969, Zekovic 1970, Kolk and KARLBERG 1973). Similar results were obtained during all the trial years. On the other hand the occurrence of $H$. gramineum varied greatly in different fields and in different provinces (Table 3). In the most important barleycultivating areas, in the south-western and southern provinces, the fungus was observed to occur the least frequently. In Ostrobothnia (EP, KP, PP) leaf stripe of barley was found more frequently than in the neighboring provinces, not including the northern parts of the country. Fields may be found where more than $1 / 3$ of the barley plants have been destroyed by leaf stripe in the late summer (Fig. 5). Results of the State Seed Testing Station substantiate these observations (Halkilahti 1971, $1973 \mathrm{~b}$ ).

Ascocarps, morphologically similar to Pyrenophora graminea or P. teres, were found only a few times on overwintered stubble of barley.

\section{Helminthosporium teres}

Helminthosporium teres Sacc., syn. Drechslera teres (Sacc.) Shoem., perfect stage: Pyrenophore teres Drechs. Syn. cf. Shoemaker 1962: 826.

The fungus causes net-blotch disease of barley. It occurs occasionally also on oats, wheat, rye and other grasses (cf. Shipton et al. 1973).

The fungus can be seed-borne as conidia or mycelium. It may over-winter also as the perfect stage on culms straw and stubble and as sclerotia on the dead leaves and on crop debris (Webster 1951, Kenneth 1962, SmedegÅdPetersen 1971, 1972 b). Seed infection is probably worse at low temperature (RAVN 1901).

$H$. teres occurs in most barley-growing countries (SPRAgue 1950, CMI map no. 364,1968 ) and has caused several kinds of damage to barley, particularly during the last years (Kenneth 1962, Evans 1969, Rintelen 1969, Melville and Lanham 1972).

In Scandinavia $H$. teres is commonly found in Sweden (FRIT 1966, KoLK 1966, Kolk and Karlberg 1973) and in Norway (Hansen and Magnus 1969, OveraA 1972), though its economic significance is small. Also in Denmark the disease has so far played a minor role (ANDERSEN 1955). During the past five years, however, there has been a marked increase in the prevalence of H. teres (SMEdEGÅRD-Petersen 1971, $1972 \mathrm{a}, 1974$. ) 


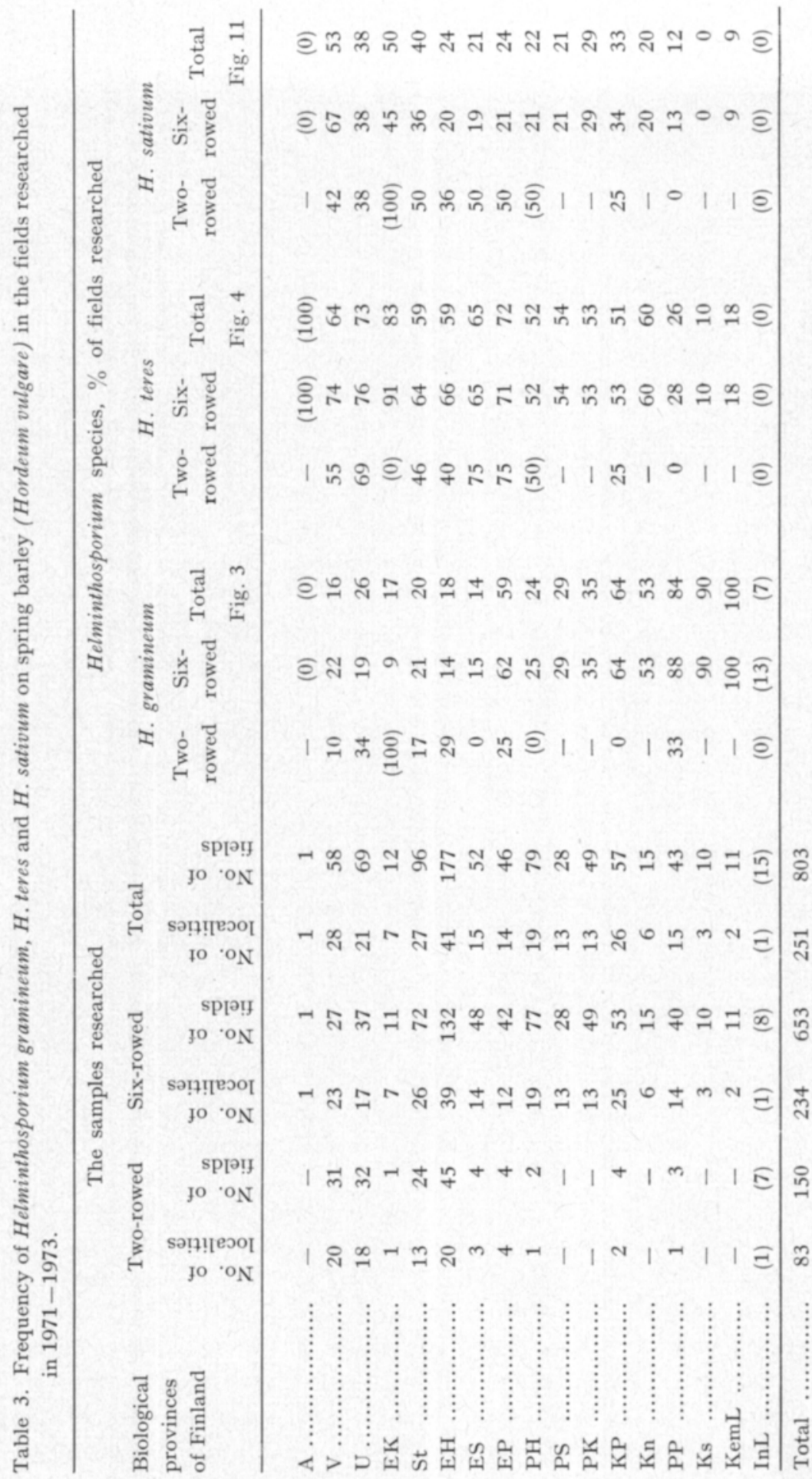




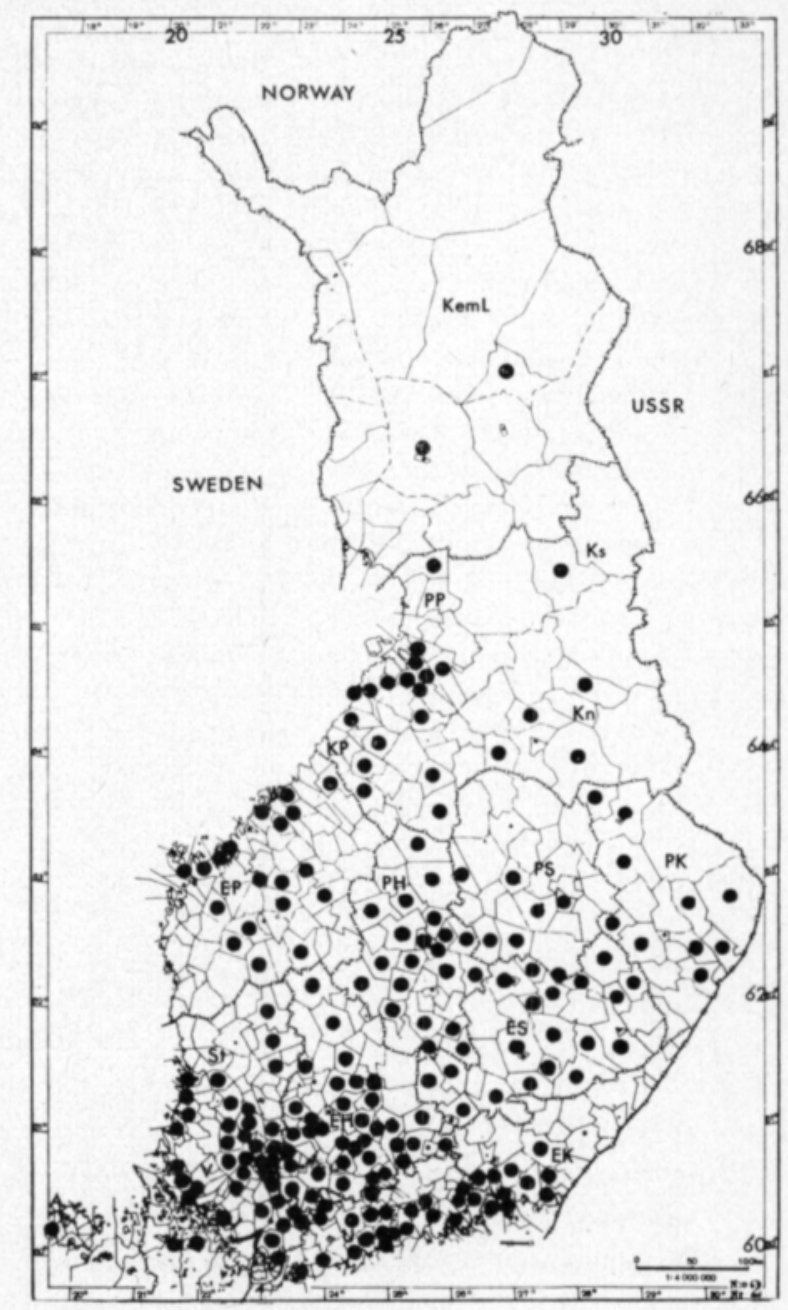

Fig. 4. The occurrence of Helminthosporium teres on spring barley (Hordeum vulgara) by localities in Finland during the period $1971-1973$.

In Finland the same trend is seen. The fungus is apparently considered to be of negligible significance because up to now it has not attracted attention. In 1970 and 1971, however, H. teres was found in over $50 \%$ of the barley fields examined (MÄKELÄ 1972).

In this study $H$. teres was encountered on barley throughout the country as far north as Kemi Lapland (Pelkosenniemi) (Fig. 4). The fungus was found in the following localities:

A: $\quad$ Eckerö;

V: Aura, Halikko, Kalanti, Karkkila, Kiikala, Korppoo, Koski Tl., Kuusjoki, Lemu, Mietoinen, Muurla, Nauvo, Nummi, Perniō, Piikkiö, Pusula, Pöytyä, Suomusjärvi, Tenhola, Vehmas, Vihti;

U: Anjala, Askola, Elimäki, Espoo, Helsinki, Hyvinkää, Inkoo, Kirkkonummi, Lapinjärvi, Liljendal, Nurmijärvi, Pernaja, Pornainen, Porvoo mlk., Pyhtää, Ruotsinpyhtää, Sipoo, Snappertuna, Vantaa, Tuusula;

EK: Karhula, Kymi, Luumäki, Miehikkälä, Sippola, Vehkalahti, Virolahti;

St: Alastaro, Eurajoki, Huittinen, Hämeenkyrö, Ikaalinen, Keikyä, Kokemäki, Kullaa, Kôyliō, Loimaa, Loimaa mlk., Luvia, Mellilä, Metsämaa, Oripää, Parkano, Pori, Punkalaidun, Rauma, Säkylä, Vampula, Yläne; 
EH: Asikkala, Hartola, Hattula, Hauho, Hausjärvi, Heinola mlk., Hollola, Humppila, Hämeenlinna, Janakkala, Jokioinen, Jämsänkoski, Kangasala, Korpilahti, Koski Hl., Kuhmalahti, Kylmäkoski, Kärkölä, Lammi, Loppi, Luhanka, Luopioinen, Nastola, Orivesi, Pälkäne, Renko, Riihimäki, Ruovesi, Sahalahti, Somerniemi, Somero, Sysmä, Tammela, Toijala, Tuulos, Urjala, Vesilahti, Viiala, Ylöjärvi;

ES: Anttola, Enonkoski, Joutsa, Juva, Kangaslampi, Leivonmäki, Luumäki, Mikkeli, Mäntyharju, Puumala, Ristiina, Sulkava, Sääminki, Valkeala;

EP: Alavus, Ilmajoki, Jalasjärvi, Kauhava, Koivulahti, Kurikka, Laihia, Lapua, Maksamaa, Mustasaari, Ylihärmä;

PH: Hankasalmi, Kannonkoski, Karstula, Keitele, Keuruu, Konginkangas, Konnevesi, Laukaa, Multia, Petäjävesi, Pihtipudas, Rautalampi, Saarijärvi, Sumiainen, Suolahti, Uurainen, Viitasaari, Virrat, Äänekoski;

PS: Joroinen, Jäppilä, Heinävesi, Kuopio, Maaninka, Pieksämäki mlk., Riistavesi, Savonranta, Suonenjoki, Varkaus, Virtasalmi;

PK: Eno, Ilomantsi, Juuka, Kiihtelysvaara, Liperi, Nurmes, Outokumpu, Tohmajärvi, Tuupovaara, Valtimo;

KP: Alajärvi, Kannus, Kruunupyy, Kärsämäki, Lappajärvi, Munsala, Kokkola, Oulainen, Pattijoki, Pietarsaari, Pyhäjoki, Pyhäjärvi, Raahe, Rantsila, Revonlahti, Sievi, Ylivieska, Åhtävä;

Kn: Hyrynsalmi, Paltamo, Sotkamo, Vuolijoki;

PP: Kempele, Kuivaniemi, Liminka, Muhos, Oulu, Rovaniemi, Temmes, Tyrnävä;

Ks: Taivalkoski;

KemL: Pelkosenniemi.

H. teres was found indifferent years in an average $57 \%$ (range $45-67 \%$ ) of the fields (803 fields) and in $87 \%$ of the localities (251 localities) examined (Table 1). The fungus was rather commoner in six-rowed varieties $(47-66 \%)$ than in two-rowed varieties $(37-68 \%)$. Also e.g. two-rowed barley cv Herta is known to be resistant to H. teres (McDonald and Buchannon 1964, Hansen and Magnus 1969).

The occurrence of $H$. teres varied greatly in different fields and different provinces (Table 3). The disease was observed to occur most commonly in the southern and southwestern parts of the country, which are the most important areas where barley is grown, and to decrease gradually towards the north. The fungus was found to be particularly rare in North Ostrobothnia and Lapland. This runs counter to $H$. gramineum, which was found to be commonest in the northern parts of the country and rarest in the most important cultivating areas (Table 3, Fig. 3).

Results were similar during all the trial years. In $1973 \mathrm{H}$. teres was found to be comparatively rarer than in 1971 and 1972, especially in Uusimaa, South Karelia and South Savo, apparently owing to weather conditions. Also the occurrence of $H$. teres varied greatly in different fields. As a rule the disease was uniform in a given field.

The fungus tainted the leaves of barley with barious kinds of spots, the commonest of which were net blotch and small leaf spot (Fig. 5). These often

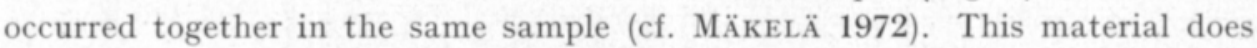
not furnish a basis for saying which type of symptom caused by $H$. teres is the commonest in Finland. Only in 1971 was the late summer sufficiently humid to study symptoms of the disease on barley leaves, whereas in 1972 and especially in 1973 barley ripened too rapidly. The spot type has been found to be somewhat 
commoner than the net blotch type both in Norway (HANsen and Magnus 1969) and in Denmark (Smedegåd-Petersen 1971).

Pycnidia were observed in less than $5 \%$ of the samples examined (MÄKELÄ 1972). The perfect stage Pyrenophora teres has not been found with certainty in Finland (cf. p. 191).

\section{Helminthosporium spp.}

Helminthosporium spp. on wheat and rye

In this study there was found on wheat and rye a fungus (or fungi) of the Helminthosporium species which is morphologically similar to $H$. gramineum and $H$. teres. The fungus was observed on rye only three times in 1972 (U: Tuusula 2. 8., St: Loimaa mlk. 22. 7., ES: Sääminki 24. 7.), and on winter wheat also three times (EH: Luopioinen 24. 7. 1972, St: Hämeenkyrö 1. 8. 1972, V: Muurla 25.7.1973). In addition Helminthosporium species were found on spring wheat in small quantities throughout the country up to North Savo (Table 4 ) in the following localities:

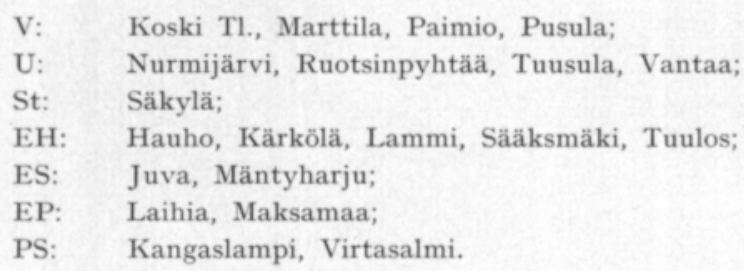

The fungus was encountered in about 11 per cent of the spring wheat fields (about 220 fields) and in $18 \%$ of the localities (111 localities) studied (Table 1). Conidia of the fungus (or fungi) were found only on ripening and withering leaves of rye and wheat on brown, necrotic spots usually in the company of other fungi (Fig. $2 \mathrm{H}, \mathrm{I}$ ). Only rare isolates have been made from leaves of spring wheat.

Besides barley, H. gramineum is known to occur in many localities, though with little importance (e.g. Pettinari 1955, Rasulev and Kavtsova 1970) in inoculation tests also on rye (RASUlev and Kavtsova 1970, MäKELÄ 1972).

Also $H$. teres has been found on wheat (cf. Sнipтом et al. 1973), in inoculation tests both on wheat and rye (MÄKEL ̈̈ 1972). H. avenae has occurred sparsely on wheat and rye (KoLK 1966).

\section{Helminthosporium tritici-repentis}

Helminthosporium tritici-repentis Died., syn. H. tritici-vulgaris Nisikado (cf. Shoemaker 1962, Hosford 1971), Drechslera tritici-repentis (Died.) Shoem., perfect stage: Pyrenophora tritici-repentis (Died.) Drechs., syn. P. trichostoma (Fr.) Fckl. (cf. Hosford 1972). Syn. cf. Shoemaker 1962: 831.

The fungus causes leaf blight and root injury on wheat and Agropyron repens (L.) PB. but is frequently found on brown necrotic leaves of many grasses (SPrague 1950, Shoemaker 1962). It appears to be a worldwide 


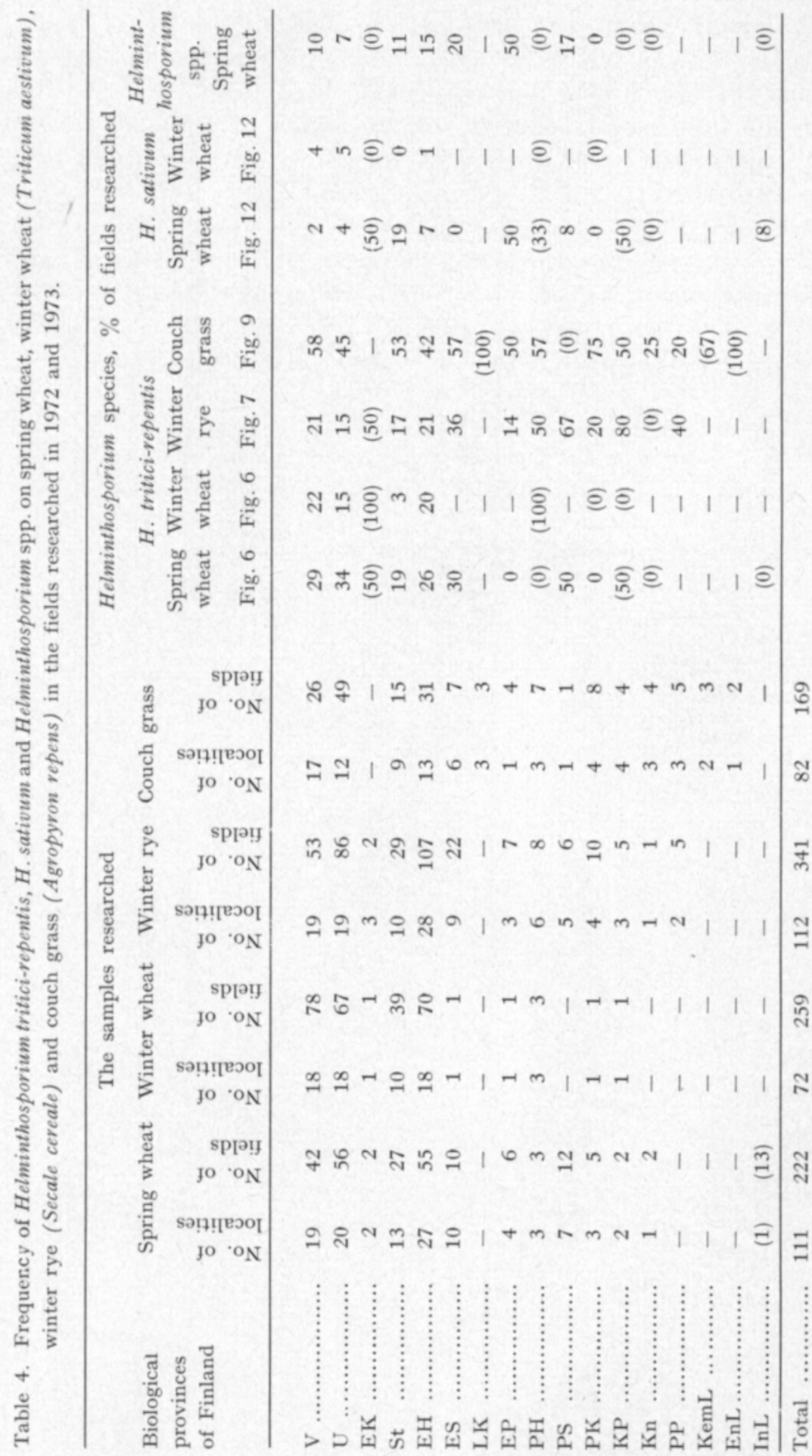


pathogen on wheat, especially on spring wheat (Triticum aestivum L.) (SPRAGUE 1950, Hosford 1971, 1972, Voítova 1971).

In Europe the fungus has played only a minor role on wheat. It was first observed in Germany in 1935 (RAABE 1937), Swirtzerland in 1959 (Аммом 1963) and Austria in 1965 (GLAESER 1966).

Only a little is known about $H$. tritici-repentis on rye (Secale cereale L.) in Poland (Garbowski 1932), the USA (Sprague 1950, EArhart 1952) and Canada (Shoemaker 1962).

On the other hand the species has been reported to be common on Agropyron repens (L.) PB. throughout the world (SPRAgUe 1950, ShoemakeR 1960). In Europe the fungus has been known since the turn of the century in Germany (NoAK 1905), Britain (Dennis and Wakefield 1946), Denmark (Andersen 1955), Poland (GARbowski 1932) and Finland (MÄKelä 1971).

Wheat

Helminthosporium tritici-repentis occurred on wheat in the southern parts of the country (Fig. 6). The fungus was common on winter wheat in the south-

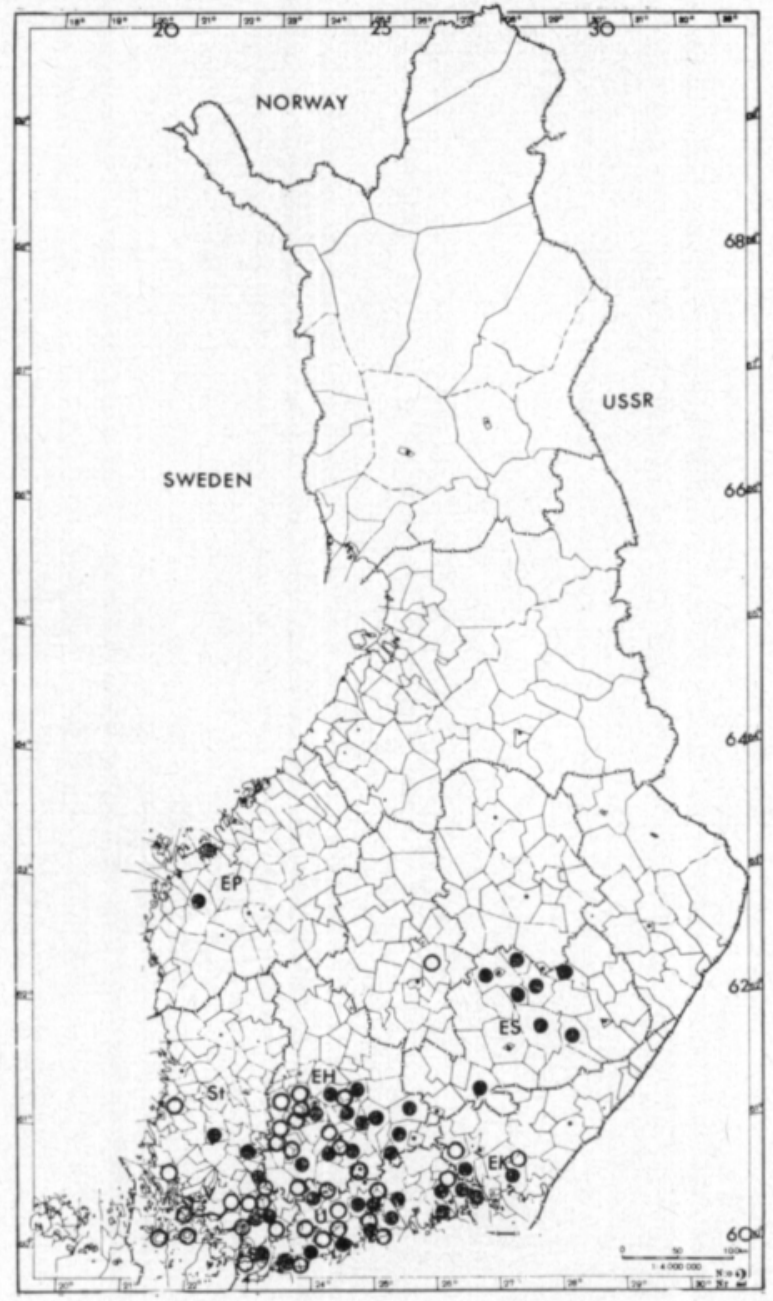

Fig. 6. The occurrence of Helminthosporium tritici-repentis on spring wheat (shaded circle) and winter wheat (open circle) (Triticum aestivum) by localities in Finland during the period 1971-1973. 
western parts of the country and on spring wheat also in South Savo and in South Ostrobothnia. These are the main wheat-cultivating areas in Finland (Table 4). The fungus was encountered in $27 \%$ of the fields of spring wheat (222 fields) and in $40 \%$ of the localities (111 localities) studied as well as in $17 \%$ of the fields of winter wheat (259 fields) and in $\mathbf{5 3} \%$ of the localities (72 localities) examined (Table 1). H.tritici-repentis was found in the following localities:

\section{Spring wheat}

V: Koski Tl., Muurla, Pusula, Salo, Tenhola;

U: Elimäki, Helsinki, Inkoo, Kirkkonummi, Liljendal, Nurmijärvi, Pernaja, Pornainen, Pyhåntää, Ruotsinpyhtää, Sipoo, Tammisaari mlk., Vantaa, Tuusula;

EK: Vehkalahti;

St: Loimaa mlk., Säkylä;

EH: Asikkala, Hauho, Hollola, Janakkala, Kärkölä, Lammi, Luopioinen, Pälkäne, Renko, Sääksmäki, Tammela, Tuulos;

ES: Juva, Mäntyharju, Sulkava;

EP: Laihia, Maksamaa;

PS: Haukivuori, Joroinen, Jäppilä, Kangaslampi, Pieksämäki, Virtasalmi;

Perfect stage: U: Helsinki (Viikki), 6. 6. 1972, Pornainen, 25. 5. 1972. V: Lohja mlk., 24, 5. 1972.

Winter wheat

V: Halikko, Kalanti, Karkkila, Kisko, Korppoo, Kuusjoki, Muurla, Nauvo, Paimio, Parainen, Perniö, Salo, Tenhola, Vehmas, Vihti;

U: Helsinki, Inkoo, Kirkkonummi, Lapinjärvi, Lohja mlk., Pornainen, Snappertuna, Tuusula, Vantaa;

EK: Vehkalahti;

EH: Forssa, Hattula, Humppila, Hämeenlinna, Iitti, Kylmäkoski, Lempäälä, Luopioinen, Riihimäki, Toijala, Urjala, Vesilahti;

PH: Laukaa.

Perfect stage: V: Perniō, 24. 5. 1972.

Spores of $H$. tritici-repentis were found in greatest abundance right often early spring (April) on winter wheat and after early summer (July) on spring wheat on ripening and whithering leaves (Fig. $10 \mathrm{G}$ ); namely, on brown necrotic spot. The perithecial stage was found accidentally on stubble in spring (Fig. 8).

\section{Winte rye}

Helminthosporium tritici-repentis was encountered in the southern parts of the country up to Middle Ostrobothnia (Fig. 7). This is Finland's rye bowl. The fungus was found in about $1 / 4$ of the rye fields studied (340 fields) and in about $1 / 2$ of the localities (112 localities) (Table 1) as follows:

V: Korppoo, Lohja mlk., Masku, Mietoinen, Nauvo, Paimio, Pöytyä, Raisio, Vehmas;

U: Helsinki, Hyvinkää, Inkoo, Tuusula;

EK: Sippola;

St: Huittinen, Ikaalinen, Kôyliö, Luvia, Oripää;

EH: Asikkala, Hattula, Hauho, Heinola mlk., Hämeenlinna, Janakkala, Kylmäkoski, Kärkölä, Luopioinen, Pälkäne, Renko, Ruovesi, Sahalahti, Sysmä, Toijala, Tuulos, Urjala, Vesilahti; 
ES: Juva, Kangaslampi, Mikkeli mlk., Mäntyharju, Puumala, Sulkava, Sääminki;

EP: Jalasjärvi;

PH: Laukaa, Pihtipudas, Sumiainen, Uurainen;

PS: Haukivuori, Jäppilä, Pieksämäki;

PK: Ilomantsi, Viinijärvi;

KP: Munsala, Raahe, Sievi;

PP: Ii, Liminka;

Perfecta stage: U: Helsinki (Viikki), 18. 5. 1972.

PS: Jäppilä, 25. 7. 1972.

Spores of $H$. tritici-repentis were foud on rye since early June. In ripening season they were observed chiefly on brown necrotic spots, streaks or necrotic areas - these may extend the length of the blade - or the tip of the blade (Fig. $8 \mathrm{~A}$ ). In addition to $H$. tritici-repentis several other parasitic species such as Septoria nodorum (Berk.) Berk. and other Septoria species, Puccinia, Fusarium species and Erysiphe graminis CD. were observed grow at the same time on the leaves of rye and wheat. Similar observations have been made elsewhere (SPRAgue 1950, Hosford 1971, 1972).

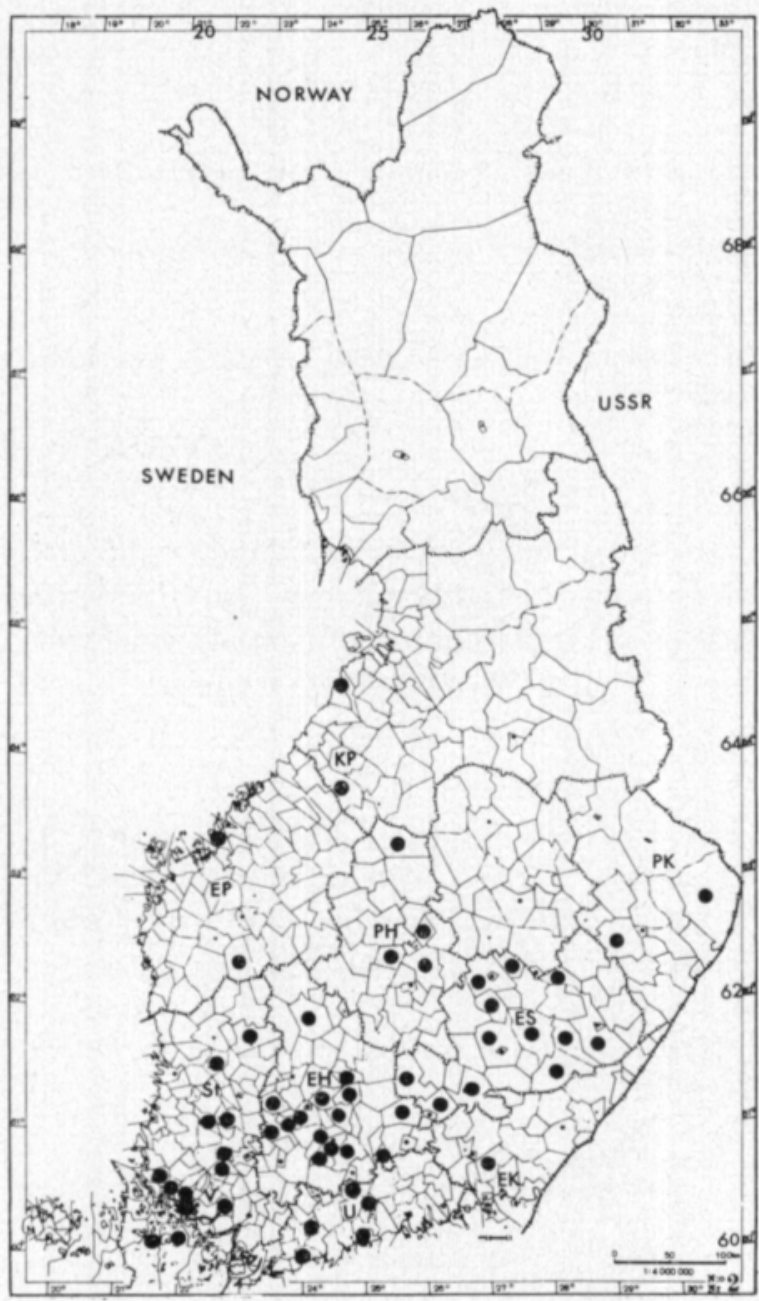

Fig. 7. The occurrence of Helminthosporium tritici-repentis on winter rye (Secale cereale) by localities in Finland during the period $1971-1973$. 

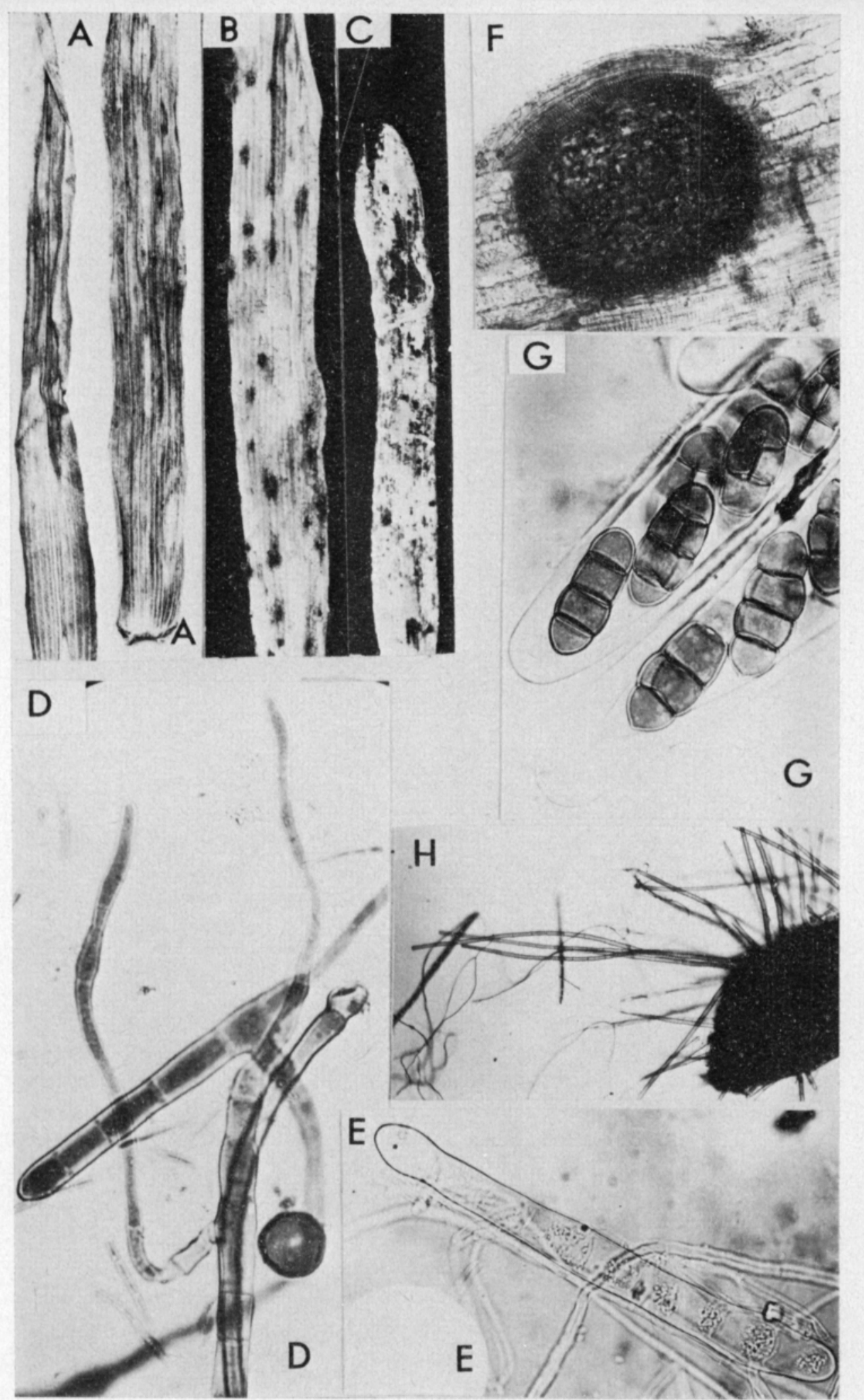

Fig. 8. Helminthosporium (Pyrenophora) tritici-repentis on winter rye (Secale cereale) (A-F) and winter wheat (Triticum asetivum) $(\mathrm{G}-\mathrm{H})$. A: the characteristic leaf lesions in the beginning of July, B: the immature pseudothecia on leaf and C: the white conidiophores and conidia of the fungi on leaf in moist blotter, D. E: conidiophores and conidia on leaves in July, F: the sclerotium in leaf, G: asci and ascospores on stubble in May, H: the sclerotium with growing conidiophores and conidia on stubble in May. A-C: x 1, D: x 500, E: x 1 000, F: x 200; G: x 500; H: x 150 . 


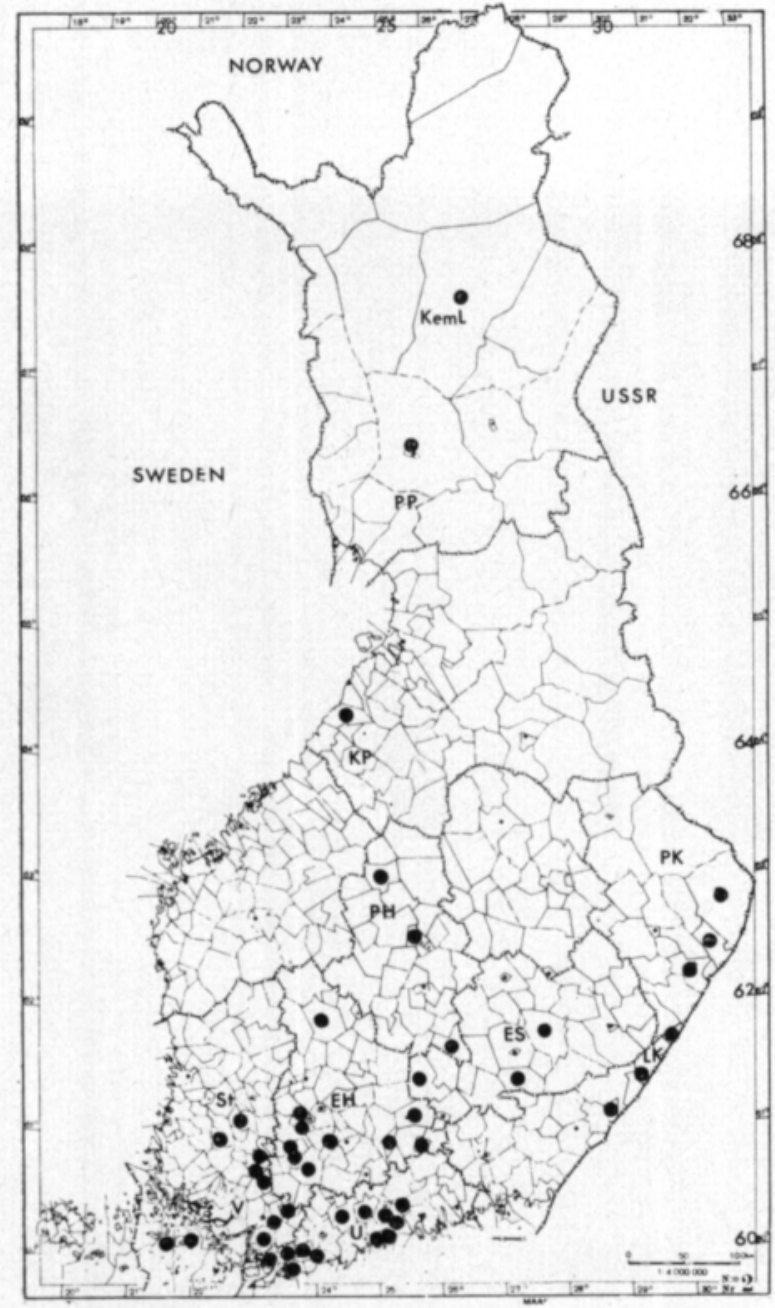

Fig. 9. The occurrence of Helminthosporium tritici-repentis cn couch grass (Agropyron repens) by localities in Finland during the period $1971-1973$.

Conidia of $H$. tritici-repentis were long, straight, cylindrical and light yellowish-brown in colour (Figs. 8 and 10) (cf. Hosford 1972). They were morphologically similar on wheat and rye.

The effect of this disease on the yield is not known. The fungus, however, is probably of small economic importance in spite of its commonness.

\section{Couch grass}

Helminthosporium tritici-repentis was found commonly throughout the country up to Lapland (Sodankylä) (Fig. 9). However, the most abundant samples were gathered in the southern parts of the country (Table 4). The fungus was found in about $1 / 2$ of the couch grass samples examined (Table 1) as follows:

V: Karjaa, Kiikala, Korppoo, Koski T1, Muurla, Nauvo, Perniö, Pohja, Tenhola, Vihti;

U: $\quad$ Helsinki, Inkoo, Kerava, Kirkkonummi, Nurmijärvi, Pornainen, Snappertuna, Vantaa;

St: Huittinen, Loimaa, Mellilä, Säkylä; 
EH: Asikkala, Forssa, Hattula, Koijärvi, Koski Hl., Kylmäkoski, Lahti, Sysmä, Tammela, Viiala;

ES: Imatra, Joutsa, Juva, Ristiina;

LK: Simpele, Uukuniemi;

PH: Kivijärvi, Ruovesi, Äänekoski;

PK: Ilomantsi, Tohmajärvi, Tuupovaara;

KP: Pyhäjoki;

PP: PP: Rovaniemi;

KemL: Sodankylä.

Perfect stage: V: Kiikala, Koski T1. 1.6.1972, Perniō 24.8. 1972, Pohja 8. 5. 1973, Tenhola 24. 5. 1972, 5. 5. 1973, Vihti 1.6.1972;

U: Helsinki 13. 5. 1968, 9. 4.1972, 30.5.1972, 4.6.1972, Inkoo 24. 5. 1972, 8. 5. 1973, Kirkkonummi 24. 5. 1972, Snappertuna 24. 5. 1972, Vantaa 28. 5. 1972;

St: Loimaa, Mellilä 1.6.1972;

EH: Forssa 1.6.1972, Koijärvi 4. 5.1967, Koski HI. 15.6. 1972, Kylmäkoski 23. 6. 1973, Lahti 9. 7. 1972, Tammela 1.6.1972;

ES: $\quad$ Imatra 29.6.1972, Juva 5. 7.1972, Mikkeli 21. 5. 1968;

LK: Simpele 29.6.1972, Uukuniemi 29.6.1972;

EP: Vöyri 17. 8. 1972;

PH: Kivijärvi 30.6.1973;

PK: Ilomantsi 3.6.1972, 4.6.1972, Tohmajärvi, Tuupovaara 30.6. 1972;

KemL: Sodankylä 2,8.1973.

The fungus produced abundant delicate blackish-brown streaks, the margins of which sometimes can be yellow, and necrotic spots or greater lesions, which were lighter in colour on the leaves and dead tips of blades (Fig. 10 A) (cf. MÄKELÄ 1971). In moist conditions the leaves were rapidly overgrown with white tufts, conidia and perithecia.

Conidia of $\mathrm{H}$. tritici-repentis was found to be most abundant on dead leaves in the early spring and the late summer; it was rather rare in the early summer. Conidia of the fungus observed on couch grass (Fig. $10 \mathrm{~F}$ ) were similar to the conidia on wheat and rye (Figs. 8 and 10 ).

Perfect stage, Pyrenophora tritici-repentis' ascomas with mature ascospores were found to be very common (about 1/4) on overwintered dead culms and leaves in early spring, May-June (Fig. 10) (cf. MäkELÄ 1971).

\section{Helminthosporium sativum}

Helminthosporium sativum Pammel, King and Bakke, syn. Bipolaris sorokiniana (Sacc. in Sorok.) Shoem., perfect stage: Cochliobolus sativus (Ito et Kurib.) Drechs. Syn. cf. Shoemaker 1959: 884.

The fungus causes root rot, seedling blight and leaf spot on cereals, above all on barley and wheat as well as on dozens of species of grasses (DRECHSLER 1923, SPRAgue 1950). In the western hemisphere, where intensive cereal cultivation is practised and where temperatures are high, H. sativum is most important as a root rot or blight of wheat and barley (SPRAGUE 1950). The fungus caused root rots of wheat also in zones with sufficient moisture in western and eastern Siberia and in the Soviet Far East (Korshunova 1968). In Europe, however, H. sativum commonly causes a leaf spot and seedling blight on barley and also, though less frequently on wheat (MüLLER 1956, Lange de la Camp 1958, de Tempe 1964). 
H. sativum survives in infected seed but can persist also in the soil (MÜLLER 1956, de Tempe 1964, Evans 1969, Shсhекоснікhina 1971, Vǒ́tova 1971, JøRGENSEN 1974).

The fungus occurs all over the world (Drechsler 1923, Sprague 1950, CMI map no. 322, 1967). In Europe, however, it is regarded as being of relatively little importance (Butler and Jones 1949, Müller 1956, de Tempe 1964). The fungus has been found on wheat and barley in Italy (Pettinari 1955), Holland (Vendrig 1956), Germany (MüLler 1956), also on rye (LANGe de la CAMP 1958) and in Britain also on oats (Evans 1969).

In Scandinavia $H$. sativum has been found sporadically in Denmark on the roots and stems of barley plants since 1930 (SKov 1966), whereas it was very common on seeds of barley, wheat and oats (ANDERSEN 1955). In recent years H. sativum has been recorded on barley seed (JøRGENSEN 1969, 1974). The fungus has also been found rather commonly on barley straw and stubble in fields (SMEDEGÅRD-Petersen 1972 a). The effect of such infections on the yield is not known.

In Norway $H$. sativum was found for the first time on barley in 1960. As a leaf spot fungus it seems to be insignificant (Hansen and Magnus 1969). whereas it was found rather commonly on barley seeds as well as on oat seed, though somewhat rarely (OvERAA 1972).

In Sweden barley seeds were highly infected by $H$. sativum, while oats, wheat and rye to a lesser extent. The fungus had a distinct pattern of occurrence in different parts of the country (FrITZ 1965, 1966, KoLK 1966).

In Finland $H$. sativum was isolated from the leaves of barley from four localities for the first time in 1970. The fungus was also found on seeds of spring wheat and winter rye produced at Viikki (Helsinki) in 1969, as well as on many grasses (MÄKEL ̈̈ 1971). In the study carried out in 1970 and 1971 $H$. sativum was observed in about 15 per cent of the barley fields examined (180 fields). It was gathered in 90 localities in southern and central Finland. In the inoculation tests ( $H$. sativum isolated from barley) all the cereals were attacked by the fungus (MÄKELÄ 1972).

\section{Barley}

H. sativum was found on barley throughout the country as far north as Kemi, Lapland (Pelkosenniemi) (Fig. 11). The fungus was found in the following localities:

V: Aura, Halikko, Kalanti, Karinainen, Karkkila, Kiikala, Kodisjoki, Kuusjoki, Laitila, Lemu, Marttila, Mietoinen, Nummi, Parainen, Perniō, Piikkiō, Pöytyä, Raisio, Suomusjärvi, Tenhola, Vihti;

U: Anjala, Askola, Espoo, Helsinki, Inkoo, Pernaja, Pornainen, Porvoo mlk., Pyhtää, Tuusula, Vantaa;

EK: Miehikkälä, Sippola, Vehkalahti, Virolahti;

St: $\quad$ Alastaro, Huittinen, Hämeenkyrö, Ikaalinen, Keikyä, Kokemäki, Loimaa mlk., Luvia, Mellilä, Metsämaa, Oripää, Parkano, Punkalaidun, Rauma, Säkylä, Vampula;

EH: Asikkala, Hattula, Hauho, Hausjärvi, Heinola mlk., Hollola, Humppila, Hämeenlinna, Jokioinen, Jämsänkoski, Korpilahti, Koski Hl., Lammi, Loppi, Luhanka, Luopioinen, Orivesi, Pälkäne, Ruovesi, Sahalahti, Somero, Sysmä, Sääksmäki, Tammela, Tuulos, Urjala, Ylöjärvi; 


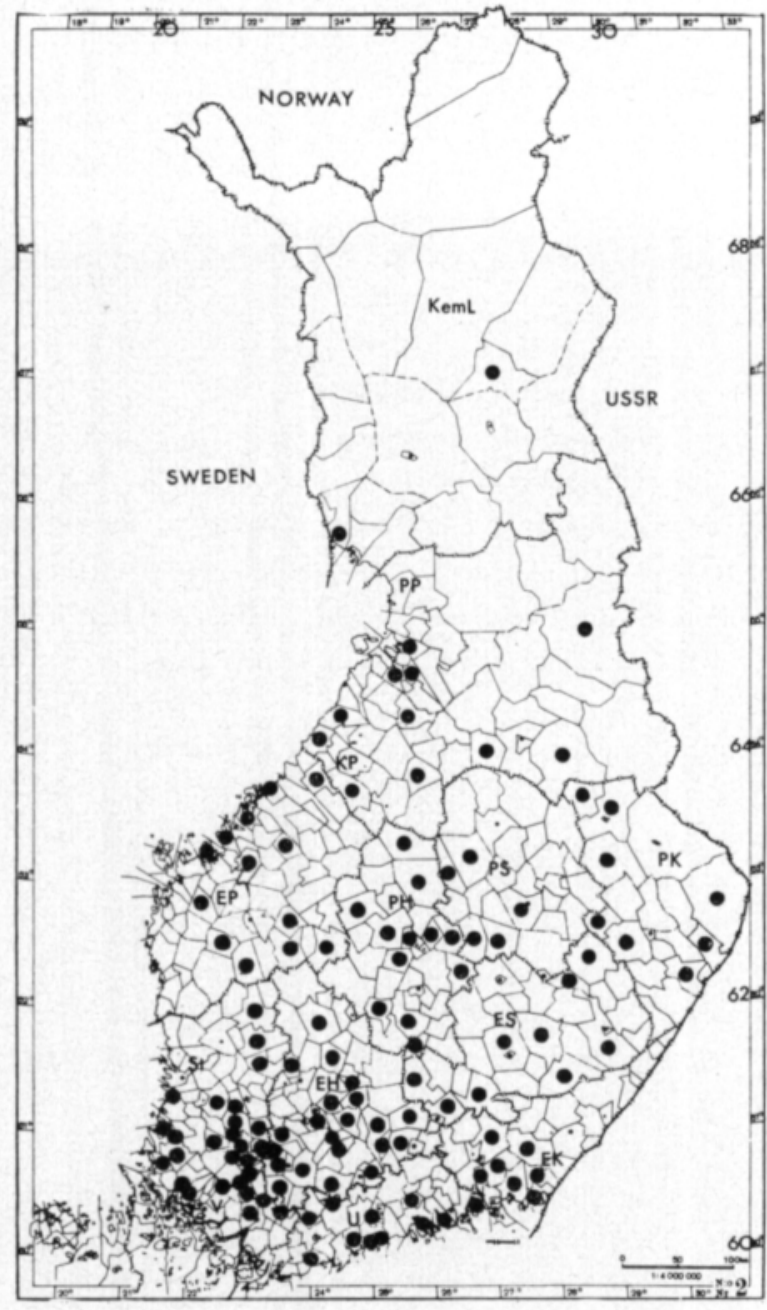

Fig. 11. The occurrence of Helminthosporium sativum on spring barley (Hordeum vulgare) by localities in Finland during the period $1971-1973$.

ES: Juva, Kangaslampi, Luumäki, Mikkeli, Mäntyharju, Puumala, Sääminki, Valkeala; EP: Alavus, Jalasjärvi, Kuortane, Kurikka, Laihia, Maksamaa;

PH: Hankasalmi, Karstula, Keitele, Konginkangas, Konnevesi, Pihtipudas, Rautalampi, Saarijärvi, Sumiainen, Uurainen, Viitasaari, Äänekoski;

PS: Heinävesi, Kuopio, Pielavesi, Suonenjoki, Tuusniemi;

PK: Ilomantsi, Juuka, Liperi, Nurmes, Outokumpu, Tohmajärvi, Tuupovaara, Valtimo; KP: Alahärmä, Evijärvi, Kalajoki, Kannus, Kokkola, Kärsämäki, Munsala, Pietarsaari, Pyhäjärvi, Rantsila, Sievi, Åhtävä;

Kn: Sotkamo, Suomussalmi, Vuolijoki;

PP: Liminka, Oulu, Tornio, Tyrnävä;

KemL: Pelkosenniemi.

H. sativum was encountered in about $1 / 3$ of the barley fields studied (about 800 fields) and in about 55 per cent of the localities (c. 250 localities) examined (Table 1). As a rule the fungus was commoner in tworowed than in six-rowed varieties (Table 3 ). The fungus was observed to be most common in the southern and southwestern parts of the country. H. sativum was rarest in northern Finland (Table 3). 
As a rule conidia of $H$. sativum grew abundantly on the ripening leaves of barley without special lesions (cf. Müller 1956, Skov 1966). Sometimes the characteristic symptoms were found on the leaves having numerous darkbrown spots either with or without a light margin (Fig. 10) (cf. LANGE de la CAMP 1958, MÄKELÄ 1972).

Also in seedlings on spring barley brown stripes and spots were observed in early summer (Fig. $10 \mathrm{H}$ ).

\section{Wheat}

H. sativum was found on spring wheat (Fig. 12) in southern Finland up to Middle Ostrobothnia (Kärsämäki). It was also found in the experimental field in Lapland (Inari, Muddusniemi). The fungus was observed to be very rare on winter wheat, occurring only in Varsinais-Suomi and in Uusimaa (Table 4). The fungus was found in the following localities:

Fig. 12. The occurrence of Helminthosporium sativum on spring wheat (shaded circle), winter wheat (open circle) (Triticum aestivum) and winter rye (Secale cereale) (triangle) by localities in Finland during the period 1971-1973.

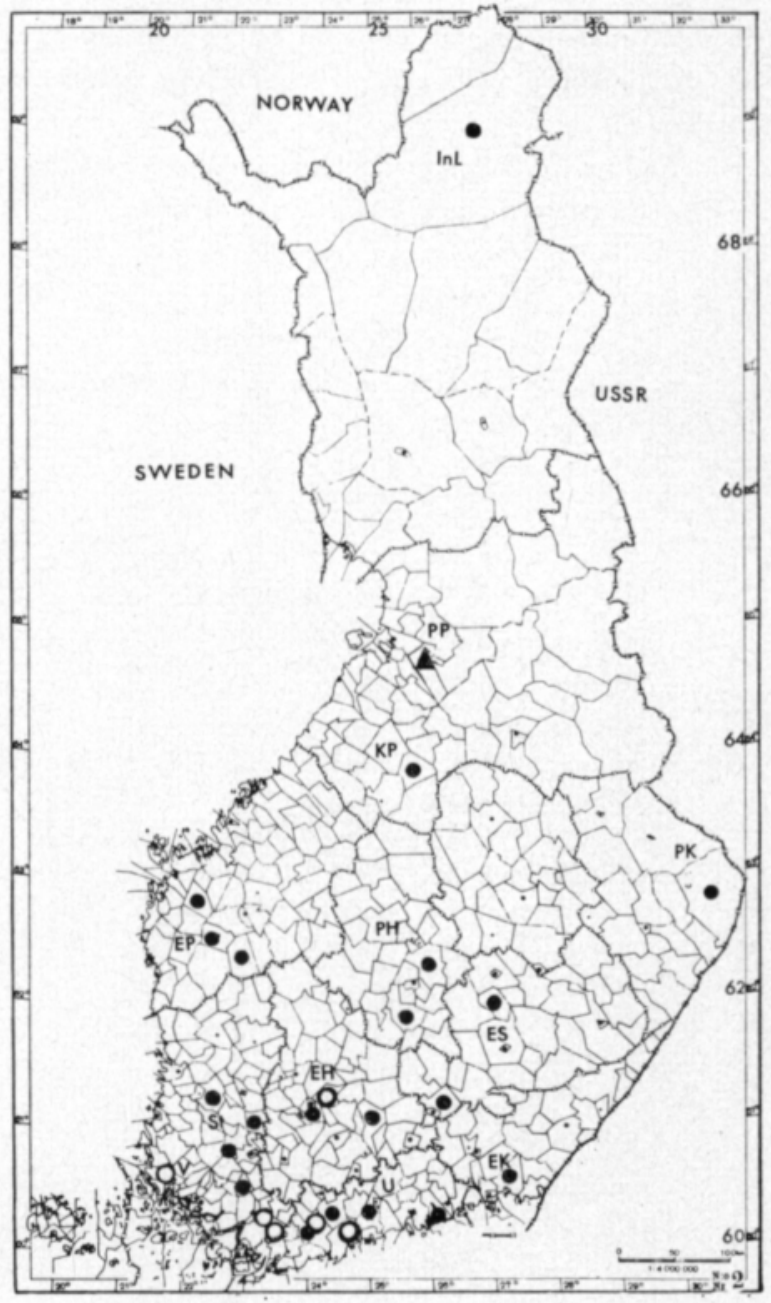


Spring wheat

V: Marttila, Vihti;

U: Pernaja, Tuusula;

EK: Vehkalahti;

St: Oripää, Peipohja, Punkalaidun;

EH: Heinola mlk., Korpilahti, Lammi, Sääksmäki;

EP: Jalasjärvi, Kurikka, Laihia;

PH: Laukaa;

PS: Haukivuori;

PK: Ilomantsi;

KP: Kärsämäki :

InL: Inari.

\section{Winter wheat}

V: Kisko, Muurla, Vehmaa;

U: $\quad$ Espoo, Lohja mlk., Tuusula;

EH: Pälkäne.

H. sativum was encountered in 9 per cent of the spring wheat fields (222 fields) and in 18 per cent of the localities (111 localities) examined and only in about three per cent of the winter wheat fields studied (about 260 fields) (Table 1).

Also in seedlings of spring wheat brown tissues were observed in early summer, 1973 in one field in Peipohja (St).

Rye

On winter rye the fungus was observed only once in North Ostrobothnia (Muhos) (Fig. 12).

Oats

H. sativum was found on oats throughout the country up to North Ostrobothnia (Tyrnävä) (Fig. 13) in the following localities:

V: Kiikala, Kuusjoki, Muurla;

U: Anjala, Askola, Elimäki, Helsinki mlk., Hyvinkää, Lapinjärvi, Pyhtää, Tuusula;

EK: Miehikkälä, Sippola;

St: $\quad$ Eurajoki, Ikaalinen, Kokemäki, Loimaa mlk.;

EH: Hausjärvi, Heinola mlk., Hämeenlinna, Korpilahti, Lammi;

ES: Hirvensalmi, Joutsa, Kangaslampi;

EP: Jalasjärvi, Laihia;

PH: Pihtipudas;

KP: Pyhäjärvi;

Kn: Paltamo;

PP: Tyrnävä.

H. sativum was found in per cent of the oat fields (415 fields) and in 17 per cent of the localities (181 localities) studied (Table 1). The fungus was found more frequently in Uusimaa than in the neighboring provinces (Table 2.) 
In late summer $H$. sativum occurred on wheat and oats together with many other fungi e.g. H. avenae, $H$. tritici-repentis and Septoria species. The symptoms caused by $H$. sativum were rather unspecific (cf. MÜLler 1956, MÄKELÄ 1972).

H. sativum was also found rather abundantly on grains of all cereals (barley, spring wheat, oats, rye) produced in fields in 1973 at Viikki (Helsinki) and at Maaninka (South Savo).

\section{Discussion}

This study was performed during the three year period 1971-1973. The meteorological conditions during the growing seasons were very similar. To be sure, there was great variation in the precipitation in different localities. The samples were gathered in different fields in different years and in part they came from different areas. The results are not given by year but are presented as a single unity. On the other hand they are grouped by biological provinces (HEIKINHEIMO and RAATIKAINEN 1971) which vary from each other in, for instance, climatic conditions, soil factors and, partially, in varieties (cv.).

Fig. 13. The occurrence of Helminthosporium sativum on oats (Avena sativa) by localities in Finland during the period 1971-1973.

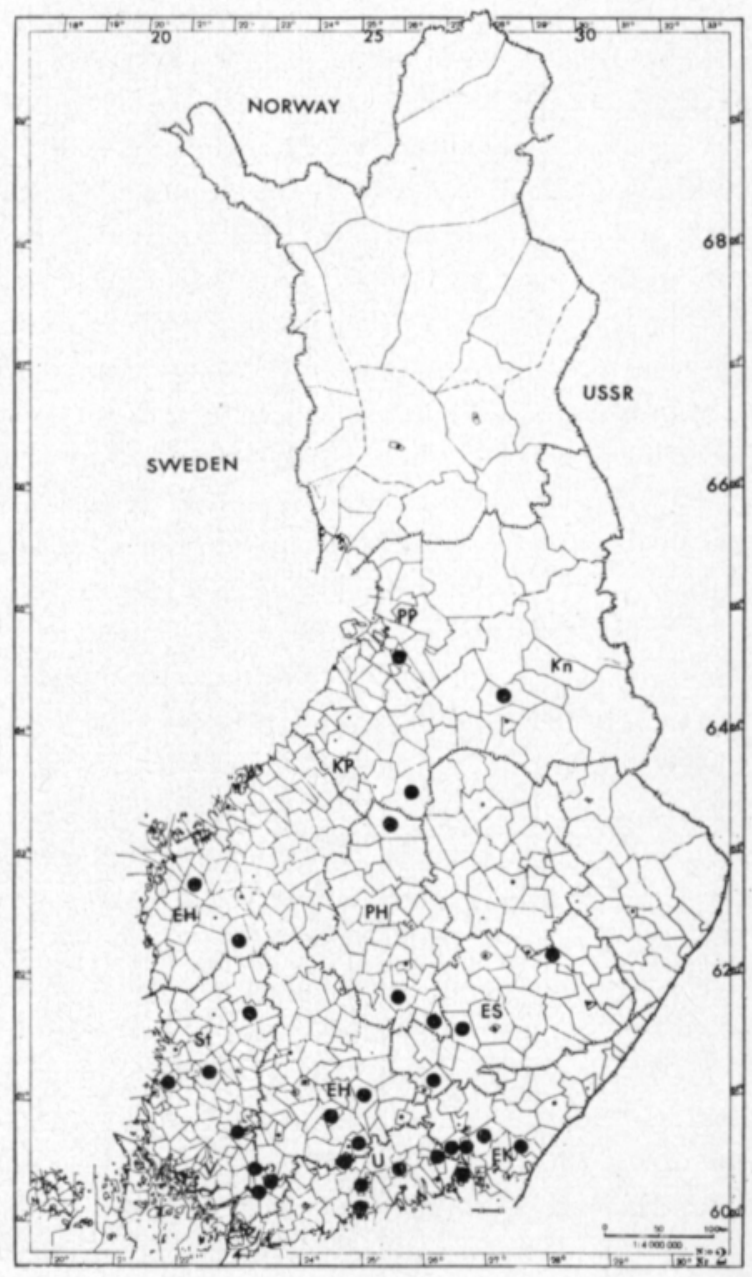


In comparing the results account should be taken not only of the above mentioned factors but also of errors that may possibly be due to the numbers of the samples. Nevertheless the possibility of error is reduced by the large number of sample localities as well as by the fact that for the most part the fungi determinations have been performed by the same individual, the researcher herself.

Helminthosporium species, above all $H$. gramineum Rabenh. ex Schlecht., $H$. teres Sacc. and H. sativum Pammel, King and Bakke on barley, H. avenae Eidam on oats and $H$. tritici-repentis Died. on wheat and rye were found to be particularley common on cereals. To date, studies along these lines have not been performed in Finland and therefore it is not known whether these diseases are on the increase in our country. This development has occurred in other Scandinavian countries in recent years, particularly in the case of barley (cf. p. 182).

H. gramineum was particularly widespread in Ostrobothnia and northern Finland. Among the many reasons for this are the cultivation of susceptible six-rowed varieties of barley. According to Halkilahti (1973 b), the main species of these, Otra, Pirkka and Pomo were more frequently and more thoroughly inoculated by $H$. gramineum than the other varieties. Neglect in the dressing of seed has been more common in the central and northern parts of the country than in the south (BLomouist 1970). The same phenomena have also been observed in other Scandinavian countries (LiHNELL 1969, OveraA 1972, KolK and KARLBerg 1973). H. gramineum also occurred on a mass scale in the USSR; the Archangel district, in particular, deserves mention (Sнснекоснікніла 1964). Furthermore, climatic factors play a considerable role in the abundant occurrence of $H$. gramineum in northern regions. This observation is supported by the fact that in this study H.teres occurred more commonly in the southern than in the northern parts of the country, whereas for $H$. gramineum the reverse was true.

$H$. teres was the most common Helminthosporium species on barley. There are probably considerable crop damages, at least in those fields in which the fungus occurs abundantly already on the seedlings. The fungus caused premature destruction of the leaves and at the same time the ears remained underdeveloped (cf. McDonald and Buchannon 1964, Rintelen 1969, SmedegårdPetersen 1974). In Norway (Hansen and Magnus 1969) and Sweden (KolK and KAlBerg 1973), however, the disease is considered to be rather insignificant.

The perfect stage of $H$. teres has not been found with certainty in Finland nor is there any evidence that the fungus persists in fields in any other form. This fact is nevertheless indicated by the extreme frequency and abundance of the fungus also in areas in which the seed is in general dressed. The fungus is known to be preserved in the straw, stubble and debris of barley on the ground surface in Britain (Evans 1969) and Denmark (SMEDEGÅRD-Petersen 1972 a). Mercurial treatment is satisfactory for controlling the seed-borne inoculum (de Tempe 1964, Smedegård-Petersen 1974).

$H$. avenae was extremely common on oats through the country. Diseasesusceptible varieties were in part responsible for this. According to HalkI- 
LAHTI's (1973 a) study of seed, Hannes, Ryhti, Sisu and Blenda, as well as Nip, which is widely cultivated in the northern parts of the country, are more frequently inoculated by $H$. avenae than are Pendek, Tiitus, Kyrö and Sörbo. In field experiments, too, (REkola et al. 1970) Hannes and Sisu were much more susceptible than Pendek.

In this study the fungus was observed in certain cases to be particularly abundant on peat lands on both seedlings and on ripening leaves. In addition, it caused considerable crop losses (Hämeenlinna, cv. Hannes) (Butler and Jones 1949). In the other Scandinavian countries the fungus is considered to be of negligible importance (ANDERSEN 1955, Fritz 1965, KolK 1966, OveRAA 1972). This may be due to differences in varieties (HALKILAHTI 1973 b) and climatic factors (DENNis 1933).

Dressing is an important method of warding off seed-borne fungus (de TEмPE 1964). In Finland, however, oats have never been dressed to the same extend as other cereals.

The commonness of $H$. sativum on cultivated fields in Finland is surprising; it occurs as far north as Lapland (Inari 69 N, 27 E) though it is regearded as being a fungus of the warm, southern regions (Butler and Jones 1949, Müller 1956). In recent years $H$. sativum has been observed also on numerous grasses throughout the country (cf. MÄKEL ̈̈ 1971). The occurrence of the fungus on all cereals as well as its frequency and abundance point to the fact that it has long been present in Finland. The exceptionally warm summers in these years have probably also contributed to this (cf. Müller 1956, JøRgenson 1974). The same conclusion is indicated by the fact that $H$. sativum occurred more frequently and more abundantly in the southernmost parts of the country and was considerably rarer in the northern parts.

Typical leaf blotch caused by $H$. sativum (LANGE de la CAMP 1958) was rare on the barley leaves in comparison with the frequency of the fungus. The reason for this may be that the temperature was too low. This may also be a reason why so little is known about the occurrence of $H$. sativum in Finland (cf. MüLler 1956). Virtually no true spores of the fungus turned up in the leaf samples. On the other hand, they developed rapidly and in abundance in the moist conditions that were employed in this study.

The significance of the fungus as a crop-reducing factor is considered to be small in the Scandinavian countries (Fritz 1965, Hansen and Magnus 1969, SMEdEgÅRD - Petersen 1972) and elsewhere in Europe (MüLler 1956, LANGe de la CAMP 1958, de Tempe 1964).

In this study $H$. sativum apparently caused yield loss, at least in certain fields. In a number of cases the fungus was observed to damage the seedlings of barley, and spring wheat. According to JøRGensen (1974), however, the seed-borne inoculum of $H$. sativum had little or no influence on the emergance of barley in the field. In preliminary seed studies the fungus was common in the seeds of all species of cereals, in which case the abundance of the fungus would seem to determine the degree of damage to the seedling (cf. de TEMPE 1964).

$H$. tritici-repentis was rather common in Finland in all the regions where wheat and rye are cultivated. Similarly, it was the most important disease 
affecting couch grass (Agropyron repens). Couch grass is a weed that grows everywhere (MUKula et al. 1969, Hultén 1971). and, accordingly, it may easily spread the disease to both rye (cf. Garbowski 1932) and wheat (MItra 1934).

The fungus is considered to be seed-borne on cereals and on wheat in particular (de TEMPE 1964). In this study the fungus was not observed in seeds. On the other hand immature pseudothecia readily developed in abundance on the leaves of cereals in moist conditions. In nature they were observed rare with certainty. However, in the dead straws and leaves of couch grass in the spring there was also an abundance of ripe ascoma with matured ascospores. The fungus probably does not have much significance on cereals in spite of its commonness.

The observations set forth in the above indicate that there are several rasons for the abundant occurrence of Helminthosporium fungi in Finland.

First, the climatic conditions are favourable to the growth of these fungi because Helminthosporium species frequently occur as serious pathogens on plantations and on natural grasses throughout the country (MÄKEL ̈̈ 1971). The normal mean temperatures during the growing months (May-August) are rather low (approx. $+9^{\circ}-+18^{\circ} \mathrm{C}$ ) even in the southernmost parts of Finland (KоLккI 1966). The most important Helminthosporium species occurring on cereals do, in fact, thrive in comparatively cool and moist conditions, particularly in their early stages of development (RAvn 1901, Dennis 1933, Shads 1934, McDonald and Buchannon 1964). In these conditions they are also most often preserved at the imperfect stage in seeds (RAvN 1901, MÜLLER 1956, de TEMPE 1964). In the present study, too, the Helminthosporium species occurred for the most part at the imperfect stage in the form of seedborne fungi, as is the case in the other Scandinavian countries, (except for part of Denmark). (SMEdegÅR-Petersen 1971, 1972 b) and in Europe in general (Butler and Jones 1949, Müller 1956, de Tempe 1964). In very warm conditions the same fungi most often develope a perfect stage (cf. KEnNETH 1962, SMedegÅRD - Petersen 1971, 1972 b). Warm weather is also favourable to secondary infection by windborne conidia (DEnnis 1933, Shads 1934, ZEKović 1970). During the period of this study the growing seasons were warmer than usual. In the summer of 1972, when the temperatures for June and July were $+2^{\circ}-+4^{\circ} \mathrm{C}$ higher than normal, with sufficient precipitation in July, Helminthosporium species occurred more abundantly than in other test years. The month of June was also very warm in 1973 but it was apperently too dry.

Second, the majority of cereals that are cultivated in Finland are domestic varieties, most of which are extremely susceptible to inoculation by Helminthosporium. This is above all true of the most commonly cultiveted, six-rowed varieties of barley and oats (HaLkilahti 1973a, $1973 \mathrm{~b}$ ).

Third, undressed seed is used for the most part in Finland. According to Blomouist (1970), during the years 1953-1968, $77 \%$ of the bread grain seed and $39 \%$ of all the grain seed was treated with mercury disinfectants. Since 1969 only preparations of the alkoxyalkyl type have been available in Finland (BLomouist 1970). 
Fourth, during the last decades the proportion of planting seed purchased in stores has increased and at the same time there has been an increase in the number of new varieties available. Being seed-borne fungi, Helminthosporium species have thus been able to spread more rapidly over large areas (cf. de TEMPE 1964).

Fifth, the shift to the exclusive cultivation of cereals instead of the former rotation with hay, especially in the southern and south-western parts of the country, has contributed to the spread of Helminthosporium species. The same can be said about the considerable increase in the acreage devoted to the cultivation of barley in recent years.

Acknowledgements. I wish to express my thanks to Mr. Jorma Kurtto, M.Sc., Mr. Aarne Kurppa, M.Sc. and Mr. Leo Mustonen, M. Sc. who assisted me in the collection of samples of cereals. I have obtained much valuable information abou $H$. avenae from Mr. Kurtto and aboutt $H$. sativum from Mr. Kurppa, who are doing research on these fungi. I am tankful to Mrs. Hilkka Koponen, M.Sc., and Mrs. Sirpa Palojärvi, M.Sc. for their technical assistance. I am grateful to the University of Helsinki and to the National Research Council for Agriculture and Forestry for their financial assistance.

\section{REFERENCES}

Ammon, H. U. 1963. Uber einige Arten aus den Gattungen Pyrenophora Fries und Cochliobolus Drechsler mit Helminthosporium als Nebenfruchtform. Phytopath. Z. 47:244-300.

ANDERsEn, H. 1955. Species of Helminthosporium on cereals and grasses in Denmark. Friesia $5,1: 80-89$.

Blomouist, H. 1970. The mercury seed treatment of cereals in Finland 1953-1968. J. Scient. Agric. Soc. Finl. 42: 131-136.

Braverman, S. W. 1960. The Helminthosporium gramineum complex and related species on cereals and forage grasses. Phytopath. 50: 688-691.

Butler, J. E. \& Jones, S. G. 1949. Plant Pathology. 979 p. London.

DENNis, R. W. G. 1933. Studies in morphology and biology of Helminthosporium avenae. Brit. Mycol. Soc. Trans. 18: 223-238.

$-\rightarrow-\&$ Wakefield, E. M. 1946. New or interesting British fungi. Brit. Mycol. Soc. Trans. 29: $141-146$.

Diedicke, H. von 1903. Ueber den Zusammenhang zwischen Pleospora und HelminthosporiumArten. I. Centralbl. Bakt. Paras. Inf. Krankh. Abt. 2, 9: 317-329.

Drechsler, C. 1923. Some graminicolous species of Helminthosporium. I. J. Agr. Res. 24: $641-740$.

Earhart, R. W. 1952. Small grain diseases of the south-eastern coastal plain, 1951-52. Pl. Dis. Rep. 36: $420-422$.

Evans, S. G. 1969. Observations on the development of leaf blotch and net blotch on Barley from Barley debris, 1968. Pl. Path. 18: 116-118.

FrıTz, T. 1965. Förekomsten av olika parasitsvampar på stråsäd från två sydsvenska områden år 1963. Medd. Stat. Centr. Frökontr. Anst. 40:44-47.

— , - 1966. Undersökning av skjutkraft hos stråsåd. Inverkan främst av utsädes burna parasitsvampar. Medd. Stat. Centr. Frökontr. Anst. 41: 42-98.

Garbowsкi, L. 1932. Spastrzezénia nad chorobami róslin uprawnych w Wielkopolsce i na Pomorzu w okresie 1928-1931 r. Prace Wydz. Chorób Róslin Państw. Inst. Naukow. Gospod. Wiejsk. w Bydgoszczy 11:3-50. (Ref. Rev. Appl. Mycol. 10:694.) 
Glaeser, G. 1966. Das Auftreten wichtiger Schadenursachen an Kulturpflanzen in Österreich im Jahre 1965. Pfl. schutzberichte 34:79-92.

Halкilahti, A. M. 1971. The infection of commercial seed of Barley by Helminthosporium gramineum. Maatilahallituksen tiedonantoja N:o 370: 33-37.

- 1973 a. Helminthosporium avenae Eidam in Oats varieties in Finland. Maatilahallituk. sen tiedonantoja N:o 377: 26-28.

- 1973 b. Ohran lajikkeiden viirutautisuus. Koetoim. ja Käyt. 30, N:o 1-2.

Hansen, L. R. \& Magnus, H. A. 1969. Leaf spot fungi on Barley in Norway. Norwegian Pl. Protect. Inst. Div. Pl. Path., Vollebekk Rep. N:o 42.

Heikinheimo, O. \& RaAtikarnen, M. 1971. The recording of localities of biological finds in Finland. Ann. Ent. Fenn. 37, 1 a: 1-27.

Нецімӓкт, U. I. 1967. Tables and maps of precipitation in Finland, 1931-1960. Suppl. Meteorologic. Yearb. Finl. 66, 2:1-22.

Hosford, R. M., Jr. 1971. A form of Pyrenophora trichostoma pathogenic to Wheat and other grasses. Phytopath. 61: 28-32.

- - 1972. Propagules of Pyrenophora trichostoma. Phytopath. 62:627-629.

Hultén, E. 1971. Atlas of the distribution of vascular plants in northwestern Europe. $531 \mathrm{p}$. Stockholm.

Jorgensen, J. 1969. Species of Fusarim and Helminthosporium on seed of Barley grown in Denmark during 1965-1967. Acta Agric. Scand. 19: 92-98.

,--1974 . Occurrence and importance of seed-borne inoculum of Cochliobolus sativus on Barley seed in Denmark. Acta Agric. Scand. 24, 1: 49-54.

Jørstad, I. 1945. Parasittsoppene på kultur- og nyttevekster i Norge. Medd. Stat. Pl. patol. Inst. N:o 1. 142 p. Oslo.

KenNeth, R. 1962. On the taxonomy, morphology and geographic origins of Pyrenophora teres Drechsler and allied species. Bull. Res. Counc. Israel 11 D: 55-82.

KoLK, H. 1966. Utsädesburna svampsjukdomar på stråsäd. Kungl. Skogs-Lantbr. Akad. Tidskr. 105: 353-375.

— - \& KArLberg, S. 1973. Bestämming av strimsjuka och bladfläcksjuka på korn enligt filterpappersmetoden. Medd. Stat. Centr. Frökontr. Anst. 48: 39-45.

KоцккI, O. 1966. Tables and maps of temperature in Finland during 1931-1960. Suppl. Meteorol. Yearb. Finl. 65, 1 a: 1-42.

Korshunova, A. F. 1968. Kornevȳe gnili Pshenits. (Root rots of Wheat.) Zashch. Rast., Mosk., 13, 9:12-14. (Ref. Rev. Appl. Mycol. 48: 36).

LANGe de la CAMP, M. 1958. Helminthosporium sativum in Mittel- und Norddeutschland. Phytopath. Z. 32:167-180.

Linnell, D. 1969. Utsädesbetning i de nordiska länderna 1968. Nordiskt symposium kring kvicksilverproblematiken. Nordforsks biocidsekretariat. p. 147-152. Stockholm.

LIRO, J. I. 1917. Tärkeimmät tuhosienet. 359 p. Helsinki.

McDonald, W. C. \& Buchannon, K. W. 1964. Barley yield reductions attributed to net blotch infection. Can. Pl. Dis. Surv. 44: 118-119.

Melville, S. C. \& Lanham, Pl. C. A. 1972. A survey of leaf diseases of Spring Barley in Southwest England. Pl. Path. 21: 59-66.

Mitra, M. 1934. A leaf spot disease of Wheat caused by Helminthosporium tritici-repentis Died. Indian J. Agric. Sci. 4, 4:692-700. (Ref. Rev. Appl. Mycol. 14: 90-91.)

Mukula, J., RaAtikainen, M., Lallukka, R. \& RaAtikainen, T. 1969. Composition of weed flora in spring cereals in Finland. Ann. Agric. Fenn. 8: 59-110.

Müller, H. E. H. 1956. Die Verbreitung von Helminthosporium sativum P., K. und B. in Bayern und seine Bedeutung als Krankheitserreger an Gerste und Weizen. Bayer. Landw. Jahrb. 33: 610-640.

MÜlLER, H. J. 1963. Untersuchungen über Blattfleckenkrankheiten des Hafers. I \& II. Phytopath. Z. 49:177-202, 266-290.

MÃ KELÄ, K. 1971. Some graminicolous species of Helminthosporium in Finland. Karstenia 12:1-31.

- 1972. Leaf spot fungi on Barley in Finland. Acta Agr. Fenn. 124, 3: 1-23.

- -1974 . Occurrence of Rhynchosporium secalis on Spring Barley and Winter Rye in Finland in 1971-1973. J. Scient. Agric. Soc. Finl. 46:103-117. 
Nомк, F. 1905. Helminthosporium gramineum Rabenh. und Pleospora trichostoma Wint. Z. Pfl.krankh. 15: 193-205.

OveraA, P. 1972. Sunhetstilstanden hos såkorn av bygg og havre sesongen 1971/1972. Meld. Stat. Frakontr. 1 juli 1971 til 30 juni 1972: 46-54.

Pettinari, C. M. 1955. Osservazioni su alucune 'elmintosporiosi' dei cereali in Italia. Bull. Staz. Pat. veg. Roma, Ser. 3, 13:157-169. (Ref. Rev. Appl. Mycol. 36: 18.)

RAABE, A. 1937. Helminthosporium tritici-vulgaris Nisikado, Erreger einer Blattfleckenkrankheit des Weizens. Phytopath. Z. 10: 111-112.

Rasulev, U. U. \& Kraotsova, T. I. 1970. Polosatyi gel' mintosporioz Yachmenya v Uzbekistane. Mikol. i Fitipatol. 4, 1: 32-34. (Ref. Rev. Appl. Mycol. 49: 357.)

Ravs, F. K. 1901. Uber einige Helminthosporium-Arten und die von denselben hervorgerufenen Krankheiten bei Gerste und Hafer. Z. Pfl.krankh. 11:1-26.

Reкola, O., Ruokola, A-L. \& Kurtti, J. 1970. Damage caused by Helminthosporium avenae Eidam on the crop yield of Oats in Finland. Acta Agric. Scand. 20: 225-229.

Rintelen, J. 1969. Untersuchungen über die Ertragsverluste durch die Netzfleckenkrankheit der Gerste (Erreger: Pyrenophora teres Drechsl. stat. con.: Helminthosporium teres Sacc.). Z. Pfl. Krankh. Pfl. Schutz 76:147-152.

Shands, R. G. 1934. Temperature studies on stripe of Barley. Phytopath. 24: 364-383.

Sнснекоснікніма, R. I. 1964. Streak spot of Barley. Rasprostranenie vreditelě i boleznei sel'skokhozyaistvennȳkh kul'tur v SSSR v $1964 \mathrm{~g}$. [Distribution of pests and diseases of crops in the U.S.S.R. in 1964] Trud $\bar{y}$ vsev. Inst. Zashch. Rast., 25, 272 p. Leningrad, Kolos Editors Polyakov, I, Ya. \& Chumakov, A. E. (Ref. Rev. Appl. Mycol. 46: 287.)

- - 1971. O sokhranenii Helminthosporium sativum P., K. et B. v. pochve. [Preservation of Cochliobolus sativus in soil.] Trudȳ vses. Inst. Zashch. Rast. 29: 75-81. (Ref. Rev. Appl. Mycol. 51: 567.)

Shipton, W. A., Khan, T. N. \& Boyd, W. J. R. 1973. Net blotch of Barley. Rev. Pl. Path. 52: $269-290$.

Shömaker, R. A. 1959. Nomenclature of Drechslera and Bipolaris, grass parasites segregated from Helminthosporium. Can. J. Bot. 37: 879-887.

- - 1962. Drechslera Ito. Can. J. Bot. 40: 809-836.

Skov, J. P. 1966. The conidial stage of Cochliobolus sativus as a potential pathogen and as cause of a disguised disease in cereals in Denmark. Friesia 8, 1: 57-75.

SMedegírd-Petersen, V. 1971. Pyrenophora teres f. maculata f. nov. and Pyrenophora teres f. teres on Barley in Denmark. Royal Veterinary and Agr. Univ. Copenhagen, Denmark Yearb. 1971: 124-144.

— - 1972 a. Rhynchosporium secalis, Cochlioboíus sativus og Pyrenophora teres på byg i Danmark. Norsk. Jordbr. Forsk. 54: 72-74.

- $-1972 \mathrm{~b}$. The periothecial and pycnidial stages of Pyrenophora teres and P. graminea in Denmark. Friesia 10: 61-85.

- -1974 . Reduction in yield and grain size of Barley due to attack by the net blotch fungus Pyrenophora teres. Royal Veterinary Agr. Univ. Yearb. 1974: 108-117.

Sprague, R. 1950. Diseases of cereals and grasses in North America. 538 p. New York.

TEMPE, J. de 1964. Helminthosporium spp. in seeds of Wheat, Barley, Oats and Rye. Proc. Int. Seed Test. Assoc. 29, 1: 117-140.

Turner, D. M. \& Millard, W. A. 1931. Leaf spot of Oats, Helminthosporium avenae (Bri. and Cav.) Eid. Ann. Appl. Biol. 18: 535-558.

Vendrig, J. C. 1956. De levenscyclus van Helminthosporium sativum P., K. en B. op tarwe en gerst. T. pl. ziekten 62,30 .

Vǒrtova, L. R. 1971. Gel'mintosporiozȳ khlebnȳkh zlakov v usloviyakh Belorussii. [Helminthosporioses of cereals under conditions of Byclorussia.] Sb. nauch. Trud. belorussk. sel.' khoz. Akad. 76: 10-15. (Ref. Rev. Appl. Mycol. 51: 46.)

Webster, J. 1951. Graminicolous Pyrenomycetes II. The occurrence of the perfect stage of Helminthosporium teres in Britain. Brit. Mycol. Soc. Trans. 34:309-317.

ZEкović, P. 1970. Prilog proučavanju Helminthosporium gramineum (Rabh.) Erikss. - parazita ječma. Zašt. bilja. Beograd. 107:17-28. (Ref. Z. Pfl. Krankh. 78: 299.) 


\title{
Helminthosporium-sienten esiintymisestä viljakasvustoissa vv. 1971-1973
}

\author{
KAIHO MÄKELÄ \\ Yliopiston kasvipatologian laitos, Viikki
}

Tutkimuksessa selvitetään Helminthosporium-lajien levinneisyyttä ja merkitystä viljoilla. Tulokset perustuvat kasvukausina 1971-1973 kautta maan, etupäässä viljelijäin pelloilta kerättyihin kasvinäytteisiin (yht. 2040 näytettä). Ohranäytteet kerättiin n. 800 pellolta 250 paikkakunnalta, kauranäytteet 415 pellolta n. 180 paikkakunnalta, kevätvehnänäytteet 220 pellolta, n. 110 paikkakunnalta, syysvehnänäytteet n. 260 pellolta n. 70 paikkakunnalta ja ruisnäytteet n. 340 pellolta n. 110 paikkakunnalta. Lisäksi tutkittiin n. 170 juolavehnänăytettä, jotka kerättiin viljapelloilta ja pientareilta n. 80 paikkakunnalta. Syynä tähän oli se, että juolavehnässä esiintyy osin samoja sieniä kuin viljoissa. Eräånä yleisimmistä viljapeltojen rikkaheinistä on sen osuus tautien levittäjänä meillä selvitettävä.

Kaikki näytteet tutkittiin silmävaraisesti ja mikroskooppisesti sekä kasvatettiin kosteissa oloissa. Lisäksi viljeltiin sieniä keinoalustalla.

Monien Helminthosporium-lajien todettiin esiintyvän viljojen kasvustoissa yleisenä ja runsaana kautta maan Lappia myöden. Koevuosina kesät olivat poikkeuksellisen lämpimiä, mutta samalla suuressa osassa maata vähäsateisia. Kesä 1972 oli Helminthosporium-sienten kannalta edullisin ja kesä 1973 epäedullisin, päätellen näiden sienten esiintymismääristä.

Yleisimmät Helminthosporium-lajit olivat seuraavat:

H. avenae Eidam esiintyi erittäin yleisenä kauralla kautta maan. Sientä todettiin lähes $90 \%$ paikkakunnista ja yli $60 \%$ tutkituista pelloista, joista valtaosa oli tuleentumisvaiheessa. Myös kauran oraissa todettiin sientä keväisin, varsinkin turvemailla. Sieni aiheuttaa kauran oraissa kaksi-kolmilehtiasteella ruskeita viirumaisia laikkuja ja oraiden kuolemista. Tuleentumisvaiheessa ilmaantuu lehtiin oranssinpunareunaisia ruskeita laikkuja ja suurempia kuolleita solukkoalueita. Tällöin tapahtuu myös jyvien saastunta. Sieni on siemenlevintäinen.

H. gramineum Rabenh. ex Schlecht., ohran viirutaudin aiheuttaja, esiintyi yleisenä kautta maan. Sientä todettiin yli 1/2 paikkakunnista ja yli 1/3 tutkituista pelloista. Yleisimpänä ja runsaimpana esiintyi sientä Pohjanmaalla sekã kautta Kainuun, Kuusamon ja Pohjois-Suomen. Näillä alueilla tapasi peltoja, joissa jopa 1/3 kasveista oli sienen tappamia ja kahutähkäisiä. Varsinaisilla viljanviljelyalueilla sientä esiintyi huomattavasti vähemmän. H. gramineum oli yleisempi monitahoisilla kuin kaksitahoisilla lajikkeilla.

H. teres Sacc., ohran verkkolaikun ja lehtilaikun aiheuttaja, todettiin ohralla kautta maan, lähes $90 \%$ paikkakunnista ja n. $60 \%$ tutkituista pelloista. Yleisimpänä ja runsaimpana sientä, esiintyi maan lounais- ja eteläosissa, parhailla viljanviljelyalueilla, vähiten maan pohjoisosissa päinvastoin kuin $H$. gramineumia. $H$. teres oli jossain määrin yleisempi monitahoisissa kuin kaksitahoisissa ohrissa. Sientä todettiin oraissa, joskus hyvinkin runsaana. Tuleentuvan ohran lehdissä tauti oli kuitenkin vasta runsaimmillaan. Pahimmin saastuneilla pelloilla saattoivat kaikki lehdet kuolla ennen aikojaan ja tähkät jäädä pieniksi, jopa kahuiksi.

H. tritici-repentis Died. esiintyi vehnässä ja rukiissa kautta niiden viljelyalueen. Sientä todettiin kevätvehnällä $27 \%$, syysvehnällä $17 \%$ ja rukiilla $23 \%$ tutkituista pelloista ja n. 1/2 tutkituista paikkakunnista. Koevuosia oli tosin vain kaksi (1972 ja 1973) ja niiden tulokset toisistaan poikkeavia. Sientä löytyi ruskeista viiruista ja laikuista useimmiten yhdessä muiden sienten, kuten Septoria-, Puccinia- ja Fusarium-lajien sekä Erysiphe graminisen kanssa. Juolavehnällä $H$. tritici-repentis todettiin vielä paljon yleisempänä kuin viljoissa, n. 1/2 tutkituista näytteistä. Myös sienen suvullista astetta Pyrenophora tritici-repentis (Died.) Drechs. esiintyi juolavehnällä n. 1/4 kerätyistä näytteistä. Onko syy sienen yleiseen esiintymiseen meillä viljoilla lôydettävissä juuri tästä, vaatii lisätutkimuksia.

H. sativum Pammel, King ja Bakke todettiin viljapelloilla kautta maan. Sientä esiintyi yleisimpänä ohralla, yli 1/2 paikkakunnissa ja n. 1/3 tutkituista pelloista, varsinkin maan lounais- ja eteläosissa, parhailla viljanviljelyalueilla. Kaksitaboisissa lajikkeissa sieni oli yleisempi kuin monitahoisissa ohrissa. H. sativumia esiintyi muissa viljoissa huomattavasti 
harvemmin kuin ohrassa. Kevätvehnällä ja kauralla todettiin sientä alle $20 \%$ paikkakunnista ja vajaassa $10 \%$ tutkituista pelloista, syysvehnällä n. $10 \%$ paikkakunnista ja alle $3 \%$ tutkituista pelloista. Sientä löytyi kautta kunkin viljan viljelyalueen, kuitenkin muita yleisempånä Uudeltamaalta kauralla ja Satakunnasta kevätvehnältä sekä Varsinais-Suomesta ja Uudeltamaalta syysvehnältä. Rukiilla todettiin $H$. sativumia vain kerran, (Muhos) H. sativumin todettiin vioittavan ennenmuuta ohran oraita.

Helminthosporium-lajien yleisyyteen Suomessa lienee useita syitä, mm. ilmasto-olot, taudinarat viljalajikkeet, peittauksen laiminlyönti, kaupasta ostetun kylvösiemenen osuuden jatkuva lisääntyminen, viljalajikkeitten vaihtuminen yhä nopeampaa tahtia, siirtyminen yhä enenevässä määrin yksipuoliseen viljanviljelyyn ja ohran viljelyalan nopea kasvu.

Helminthosporium-sienten aiheuttamien tautien vaikutukset satoon jäivät selvittämättä. Ainakin $H$. gramineum, $H$. teres ja $H$. sativum ohralla sekä $H$. avenae kauralla ovat siksi yleisiä tautien aiheuttajia kautta maan, että niiden merkitystä ja biologiaa olisi tutkittava edelleen. 